BRUNO MACHADO BERTASSOLI

\title{
Obtenção, cultivo e expansão de células-tronco do saco vitelino de suínos domésticos (Sus scrofa)
}




\section{Obtenção, cultivo e expansão de células-tronco do saco vitelino de suínos domésticos (Sus scrofa)}

Dissertação apresentada ao Programa de Pós-Graduação em Anatomia dos Animais Domésticos e Silvestres da Faculdade de Medicina Veterinária e Zootecnia da Universidade de São Paulo para obtenção do título de Mestre em Ciências

Departamento:

Cirurgia

Área de concentração:

Anatomia dos Animais Domésticos e Silvestres

Orientador:

Prof. Dr. Antonio Chaves de Assis Neto

São Paulo 
Autorizo a reprodução parcial ou total desta obra, para fins acadêmicos, desde que citada a fonte.

DADOS INTERNACIONAIS DE CATALOGAÇÃO-NA-PUBLICAÇÃO

(Biblioteca Virginie Buff D’Ápice da Faculdade de Medicina Veterinária e Zootecnia da Universidade de São Paulo)

T.2692 Bertassoli, Bruno Machado

Obtenção, cultivo e expansão de células-tronco do saco vitelino de suínos domésticos (Sus FMVZ scrofa) / Bruno Machado Bertassoli. -- 2012.

$76 \mathrm{f}$. : il.

Dissertação (Mestrado) - Universidade de São Paulo. Faculdade de Medicina Veterinária e Zootecnia. Departamento de Cirurgia, São Paulo, 2012.

Programa de Pós-Graduação: Anatomia dos Animais Domésticos e Silvestres.

Área de concentração: Anatomia dos Animais Domésticos e Silvestres.

Orientador: Prof. Dr. Antonio Chaves de Assis Neto.

1. Células-tronco mesenquimais. 2. Cultura celular. 3. Membranas extraembrionárias. 4. Saco vitelino. 5. Sus scrofa. I. Título. 
UNIVERSIDADE DE SÃO PAULO

FACULDADE DE MEDICINA VETERINÁRIA E ZOOTECNIA

Comissão de Ética no uso de animais

\section{CERTIFICADO}

Certificamos que o Projeto intitulado "Obtenção, cultivo e expansão de células tronco do saco vitelino de suínos domésticos (Sus scrofa)", protocolado sob o $\mathrm{n}^{\circ}$ 2659/2012, utilizando 20 (vinte) suínos, sob a responsabilidade do Prof. Dr. Antônio Chaves de Assis Neto, está de acordo com os princípios éticos de experimentação animal da "Comissão de Ética no uso de animais" da Faculdade de Medicina Veterinária e Zootecnia da Universidade de São Paulo e foi aprovado em reunião de 20/6/2012.

We certify that the Research "Obtainment, cell culture and expansion of stem cells of pig's yolk sac (Sus scrofa)", protocol number 2659/2012, utilizing 20 (twenty) pigs, under the responsibility Prof. Dr. Antônio Chaves de Assis Neto, agree with Ethical Principles in Animal Research adopted by "Ethic Committee in the use of animals" of the School of Veterinary Medicine and Animal Science of University of São Paulo and was approved in the meeting of day 6/20/2012.

São Paulo, 12 de julho de 2012.

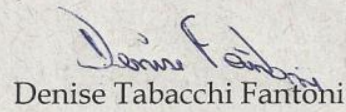

Presidente 
Nome: BERTASSOLI, Bruno Machado

Título: Obtenção, cultivo e expansão de células-tronco do saco vitelino de suínos domésticos (Sus scrofa)

Dissertação apresentada as Programa de Pós-Graduação em Anatomia dos Animais Domésticos e Silvestres da Faculdade de Medicina Veterinária e Zootecnia da Universidade de São Paulo para obtenção do título de Mestre em Ciências

Data:

\section{Banca Examinadora}

Prof.Dr

Instituição: Julgamento:

Prof. Dr.

Instituição: Julgamento:

Prof. Dr. Instituição: Julgamento: 


\section{DEDICATÓRIA}

Aos meus pais, Elisia e Luiz Carlos, que já não se encontram mais entre nós, e tenho certeza de que onde estiverem sempre olharam e cuidaram de minha pessoa.

Dedico esse trabalho a minha família, pois sem ela, tenho grande certeza de que não estaria onde estou e não teria conseguido o que consegui até hoje. 


\section{AGRADECIMENTOS}

Agradeço em especial ao meu Orientador, Antônio Chaves de Assis Neto, que apesar de nossas discussões, sempre mostrou ser um orientador exemplar, acreditando em mim quando ninguém acreditava, e me dando a chance de terminar este trabalho.

Agradeço também em especial, a doutoranda Sonia Will e Pós-doutoranda, Paula Fratini, por tudo, tudo mesmo, sem exceção. Desde o inicio foi difícil, porém sempre acreditando chegamos ao final.

Aos "Assisetes": Amilton (Capitão), Franceliusa (Natal), Paulo (Rubisco), Dani (Brags), Maria Angélica (M.A.), Vitória, Diego (Maranhão), sendo sempre minha família paulistana.

Amigos, colegas, professores e funcionários do laboratório do Setor de Anatomia dos Animais Domésticos e Silvestres, em especial à Prof ${ }^{a}$ Maria Angélica Miglino.

Ao Danilo, por ter realmente me mostrado o que é viver e ser feliz.

As professoras Ana Flávia de Carvalho e Celina Almeida Furlanetto Mançanares, porque sem elas eu também não estaria onde estou.

Aos amigos de Belo Horizonte e de São Paulo em geral.

À FAFESP e a CAPES por financiar esta pesquisa. 
Há pessoas que desejam saber só por saber, e isso é curiosidade; outras, para alcançarem a fama, e isso é vaidade; outras, para enriquecerem com a sua ciência, $e$ isso é um negócio torpe; outras, para serem edificadas, e isso é prudência; outras, para edificarem os outros, e isso é caridade"

(S. Tomás de Aquino) 


\section{RESUMO}

BERTASSOLI, B. M. Obtenção, cultivo e expansão de células-tronco do saco vitelino de suínos domésticos (Sus scrofa). [Obtainment, cultivation and expansion of stem cells from the yolk sac of domestic Pigs (Sus scrofa)]. 2012. $76 \mathrm{f}$. Dissertação (Mestrado em Ciência) - Faculdade de Medicina Veterinária e Zootecnia, Universidade de São Paulo, São Paulo, 2012.

Anexos fetais como cordão umbilical, membrana amniótica e líquido amniótico foram recentemente sugeridos como fontes ideais de diferentes linhagens de célulastronco, devido à natureza não invasiva do procedimento de isolamento, a grande massa de tecido para colheita de células com alta eficiência e os potenciais de diferenciação. Portanto, o presente estudo teve como objetivo analisar morfologicamente as membranas extraembrionárias através de microscopia de luz e imunohistoquímica e analisar as células oriundas do saco vitelino suíno visando caracterizar qual seu potencial como possível fonte de células-tronco pluripotentes, para futuro uso na terapia regenerativa. Para a imunohistoquímica das membranas, as membranas foram processadas pelas técnicas rotineiras de histologia e em seguida os blocos foram cortados sequencialmente e colocados em laminas previamente silanizadas, o protocolo de imunohistoquímica foi o convencional utilizando os seguintes anti-corpos: Citoqueratina e VEGF. Foram feitos ensaios de concentração e viabilidade celular, avaliação do crescimento celular, caracterização por citometria de fluxo utilizando anticorpos específicos (CD105, NANOG, CD45 e Oct-3/4) e caracterização por imunohistoquímica utilizando os seguintes anti-corpo: CD90, CD105, CD117, Vimentina, Stro-1, Oct-4, VEGF, Beta Tubulina, Citoqueratina e PCNA. O saco vitelino situava-se na porção ventral do embrião, próximo ao cordão umbilical, se mostrando como uma estrutura pequena, contendo poucos vasos e com coloração amarelada, este também apresentou como uma estrutura trilaminar (endoderma, mesênquima e mesotélio), onde a endoderme possuía um epitélio simples cubico, o mesênquima possuindo uma grande quantidade de tecido conjuntivo e o mesotélio contendo células achatadas. O amnio mostrou-se ligado intimamente ao embrião, sendo a primeira membrana fetal considerando a ordem embrião/útero, possuía forma oval e coloração transparente, histologicamente esta membrana é composta por 2 camadas distintas, um epitélio simples pavimentoso e um mesênquima contendo uma substancia amorfa com pouca quantidade de 
células. A membrana coriônica mostrou-se pouco rugosa e a membrana alantóidea como uma estrutura em forma de meia lua, possuindo uma intensa vascularização, conforme a evolução da gestação fica quase impossível à percepção das duas, formando a membrana córioalantoidea. O córion é constituído por uma camada de células arredondadas, dispostas em formato linear, já o alantoide é caracterizado por seu mesênquima amorfo com uma quantidade pequena de células. Em relação a imunohistoquima todas as membranas expressaram os marcadores VEGF e Citoqueratina. As celulas do saco vitelino mostraram aderência ao plástico e possuindo uma morfologia fusiforme, semelhante a fibroblastos, estas atingiram a confluência de $70 \%$ em aproximadamente 20 dias, estas celulas foram mantidas ate a passagem 4, onde posteriormente ocorreu morte celular. Estas celulas possuíam imunofenoipagem semelhante as celulas-tronco mesênquimais e hematopoiéticas, expressando marcadores como CD105, CD90, CD117, Vimentina, Stro-1, Oct-4, VEGF, Beta Tubulina, Citoqueratina, Nanog e PCNA. Do estudo realizado pode-se concluir que: existem células especificas em cada membrana extraembrionária, e que as celulas oriundas do saco vitelino possuem características semelhantes as celulas-tronco mesênquimais e embrionárias, sendo considerada uma ferramenta importante para futuros estudos experimentais de terapia celular na medicina veterinária regenerativa.

Palavras-chave: Células-tronco mesênquimais. Cultura celular. Membranas extraembrionárias. Saco vitelino. Sus scrofa. 


\section{A BSTRACT}

BERTASSOLI, B. M. Obtainment, cultivation and expansion of stem cells from the yolk sac of domestic pigs (Sus scrofa). [Obtenção, cultivo e expansão de células-tronco do saco vitelino de suínos domésticos (Sus scrofa)]. 2012. $76 \mathrm{f}$. Dissertação (Mestrado em Ciência) - Faculdade de Medicina Veterinária e Zootecnia, Universidade de São Paulo, São Paulo, 2012.

Fetal attachments as umbilical cord, amnion and amniotic fluid have recently been suggested as ideal sources of different strains of stem cells, due to the noninvasive nature of the isolation procedure, the large mass of tissue to harvest cells with high efficiency and potential differentiation. Therefore, this study aimed to analyze morphologically membranes extraembryonic by light microscopy and immunohistochemistry and analyze the cells from the yolk sac to characterize this cells as to potential as a possible source of pluripotent stem cells for future use in regenerative therapy. For immunohistochemistry, the membranes were processed by routine histological techniques, and then the blocks were cut sequentially and placed on silanized slides previously, the protocol was the immunohistochemistry conventional using the following antibodies: Cytokeratin and VEGF. Trials were made for concentration and cell viability, cell growth evaluation, and the characterization by flow cytometry using specific antibodies (CD105, NANOG, CD45 and Oct-3/4) and characterization by immunohistochemistry using the following antibody: CD90, CD105, CD117, vimentin, Stro-1, Oct-4, VEGF, beta tubulin, Cytokeratin and PCNA. The yolk sac stood in the ventral portion of the embryo near the umbilical cord, proving how a structure small, few vessels and with yellowed, this also presented as a trilaminar structure (endoderm, mesenchyme and mesothelium), where the endoderm had a simple cubic epithelium, the mesenchyme with a large amount of connective tissue and the mesothelium with flattened cells. The amnio shown to be deeply linked to the embryo, being the first membrane fetal considering the order embryo/uterus, and had oval-shaped transparent coloring, histologically this membrane is composed of two distinct layers, a simple squamous epithelium and mesenchyme containing an amorphous substance with a small amount of cells. The chorionic membrane showed little wrinkles and alantoic membrane structure as a crescent-shaped, having an intense vascularization, and the evolution of the pregnancy is almost impossible the perception of the two, forming the membrane 
chorioallantoid. The corium is constituted by a layer of round cells, arranged in linear format, as the allantois is characterized by its mesenchyme amorphous with a small amount of cells. Relative to immunohistochemical all membranes expressing VEGF and cytokeratin markers. The yolk sac cells showed adherence to plastic and a spindle-like morphology, similar to fibroblasts, they reached confluence of $70 \%$ in about 20 days, these cells were maintained until passage 4, where later cell death occurred. These cells had similar imunofenoipagem the mesenchymal stem cells and hematopoietic cells expressing markers such as CD105, CD90, CD117, vimentin, Stro-1, Oct-4, VEGF, Beta Tubulin, Cytokeratin, Nanog and PCNA. From the study it can be concluded that: there are specific cells in each extraembrionária membrane, and that the cells derived from the yolk sac have characteristics similar to mesenchymal stem cells and embryonic, and being considered an important tool for future experimental studies of cell therapy in medicine veterinary regenerative.

Key-words: Cell culture. Extrambryonics membranes. Mesenchymal stem cell. Yolk sac. Sus scrofa. 


\section{LISTA DE FIGURAS}

Figura 1 - Esquema das membranas extraembionárias em desenvolvimento .22

Figura 2 - Fotomacrografia de embriões suínos com gestação de 20 dias, notar a diferença de desenvolvimento embrionário em uma mesma gestação

Figura 3 - Fotomacrografia de embriões suínos. A) Embrião de suínos com 20 dias de gestação. Embrião (Circulo pontilhado), Alantóide (Al) e Córion (Co). B) Embrião com 20 dias. Notar saco vitelino com coloração transparente $\left(^{*}\right)$, âmnio (seta), alantóide muito vascularizado (Al) e Córion (Co). C) e D) Embrião com 30 dias. Saco vitelino com coloração amarelada já em regressão $\left({ }^{*}\right)$, âmnio (seta), córion (Co) e alantóide (Al) já em justaposição, embrião (E)

Figura 4 - Fotomicrografia do saco vitelino de embriões suínos com 20 e 30 dias de gestação. A/C/E/G membranas 20 dias e B/D/F/H membranas 30 dias. A e B) Histologia do saco vitelino: composição das 3 camadas do saco vitelino, Endotélio (Em, seta), Mesênquima (Mq), Mesotélio (circulo). C e D) Histologia do saco vitelino: llhas vasculares nas porções do saco vitelino. Notar ainda em "D" revestimento das ilhotas com células endoteliais e, interior, hemangioblastos (hemácias nucledas). Coloração, H/E. Imunohistoquímica do saco vitelino de embriões suínos de 20 dias (E/F) e 30 dias $(G / H)$. E e F) Detecção de Citoqueratina; $G$ e H) Detecção de VEGF. Mesênquima (Mq) e endotélio (En).

Figura 5 - Fotomicrografia do saco vitelino de embriões suínos com 20 e 30 dias de gestação. A/C/E/G membranas 20 dias e B/D/F/H membranas 30 dias. Histologia das membranas córioalantíde: A) Corion, células globosas arredondadas (seta) do cório. B) Alantóide (Al) com células não alongadas (circulo pontilhado) e vasos (Asterisco amarelo). C) Córionalantóide. Células globosas no córion (setas finas), Córion (Co) e Alantóide (Al). D) 
Mesênquima do alantóide (Al) com células alongadas (Circulo pontilhado). Coloração H/E. Imunohistoquímica da membrana do corioalantóide de embriões suínos de 20 dias (E/F) e 30 dias $(G / H)$. E e F) Detecção de Citoqueratina; $G$ e H) Detecção de VEGF.

Figura 6 - Fotomicrografia da membrana Amniótica de embriões suínos com 20 e 30 dias de gestação. A/B/E/G membranas 20 dias e $\mathrm{C} / \mathrm{D} / \mathrm{F} / \mathrm{H}$ membranas 30 dias. Histologia: $\mathrm{A}$ e B) Âmnio de embriões com 20 dias de gestação, células arredondadas e achatadas (seta) e mesênquima amorfo (M). C e D) Âmnio de embriões com 30 dias de gestação, células achatadas (seta) e mesênquima amorfo (M). Coloração $\mathrm{H} / \mathrm{E}$. Imunohistoquímica da membrana amniótica de embriões de suínos de 20 dias (E/G) e 30 dias $(F / H)$. E e F) Detecção de Citoqueratina; $G$ e $H$ ) Detecção de VEGF. Mesênquima (Mq) e epitélio simples cubico (setas).

Figura 7 - Fotomicrografia das células derivadas do saco vitelino de suínos com 20 e 30 dias de gestação. Em A, explant de células de saco vitelino suíno de embrião de 20 dias, notar células de formato arredondado, com núcleo centralizado; em $\mathrm{B}$, explant de células de saco vitelino suíno de embrião de 30 dias, observar células alongadas, fusiformes.; C e D) Cultura primária das células aderentes, antes da primeira tripsinização (Aumento 20x). Observar células dispersas aderidas ao redor do explant de tecido embrionário (em $\mathrm{C}$ ) e células aderidas ao plástico com formato fibroblastóide em $\mathrm{D}$. Observamos algumas diferenças na morfologia celular entre as células de 20 e 30 dias, diferenças estas sumarizadas na conclusão deste trabalho

Figura 8 - Curva de crescimento das células do saco vitelino suíno (SVS) $1.10^{5}$ celulass $/ \mathrm{mL} x$ tempo em dias (24hs)

Figura 9 - Citometria de Fluxo. Gráfico mostrando a porcentagem células de saco vitelino com 30 dias de gestação positivas para os marcadores CD105, CD45, Nanog e Oct3/4

Figura 10 - Citometria de fluxo complementar do gráfico demonstrando 
células positivas para os marcadores CD105, Nanog, CD45 e OCT $4 / 3$.

Figura 11 - Imunocitoquímica das CTMs do saco vitelino de suínos com 30 dias de gestação. Positividade para os marcadores CD90, CD105, CD117, Vimentina, Stro-1, OCT-4.

Figura 12 - Imunocitoquímica das CTMs do saco vitelino de suínos com 30 dias de gestação. Positividade para os marcadores VEGF, Beta tubulina, Ck, PCNA. .58 


\section{SUMÁRIO}

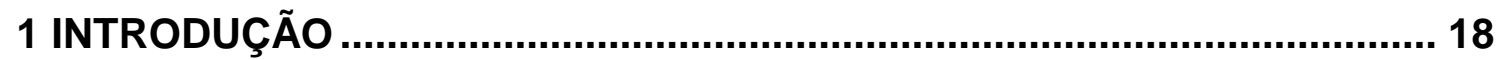

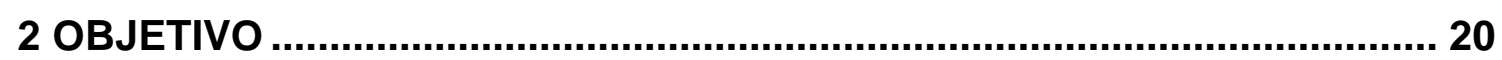

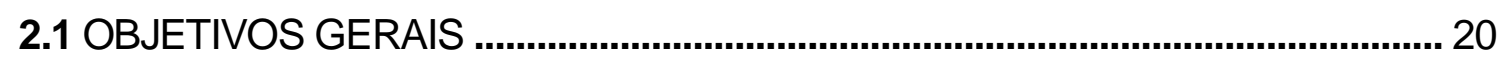

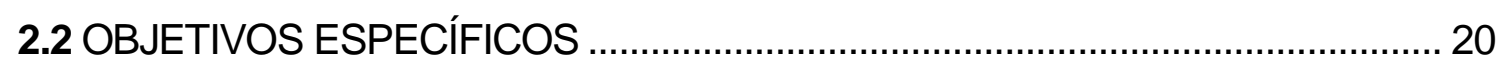

3 REVISÃO DA LITERATURA ......................................................... 21

3.1 PLACENTA E MEMBRANAS EXTRA-EMBRIONARIAS: CÓRIO, ÂMNIO,

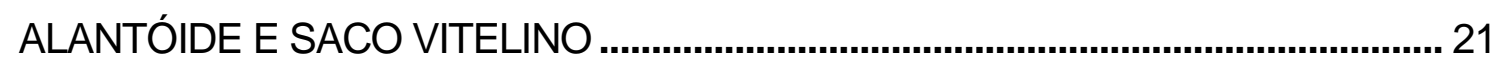

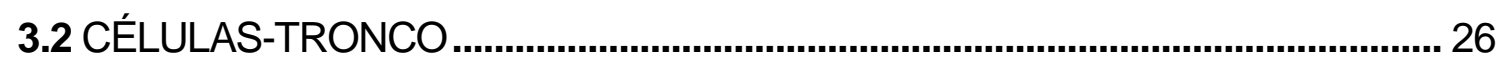

3.3 CÉLULAS-TRONCO EMBRIONÁRIAS SUÍNAS............................................. 27

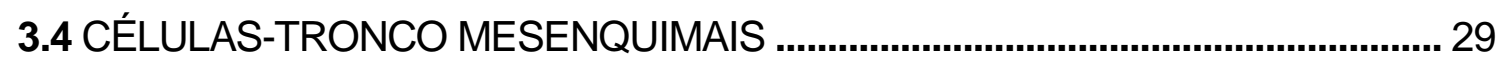

3.5 REAÇÃO DE IMUNOHISTOQUIMICA PARA DETECÇÃO DE

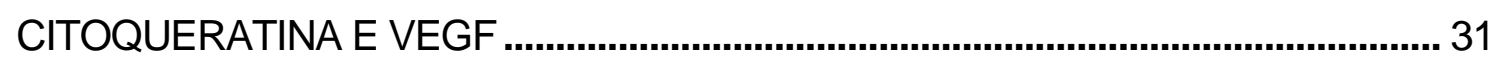

4 MATERIAL E MÉTODO

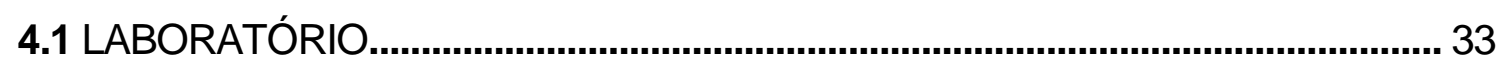

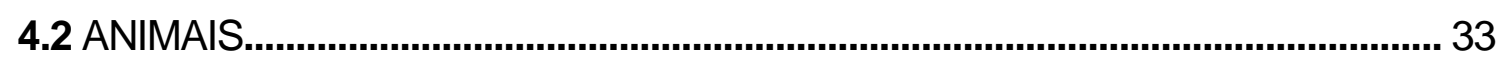

4.3 COLETA DE EMBRIÕES E MEMBRANDAS DE SUINOS............................... 33

4.4 MICROSCOPIA DE LUZ DAS MEMBRANAS .................................................... 34

4.5 IMUNOHISTOQUIMICA: DETECÇÃO DE CITOQUERATINA E VEGF ............. 35

4.6 COLETA DE CÉLULAS DE SACO VITELINO .................................................... 37

4.7 ESTABELECIMENTO DA LINHAGEM DE CÉLULAS DO SACO VITELINO..... 37

4.7.1 Protocolo de cultivo celular para o saco vitelino ........................................... 37

4.7.2 Dissociação enzimática das células aderentes: repique celular ............... 38

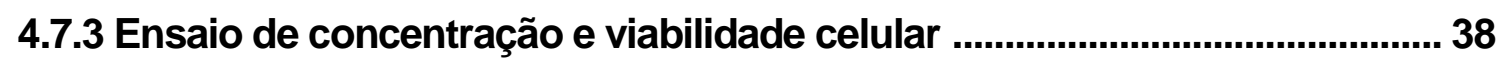

4.7.4 Avaliação do crescimento celular: curva de crescimento ........................ 39

4.8 CONGELAMENTO E DESCONGELAMENTO CELULAR ................................ 39

4.9 MORFOLÓGICA CELULAR .......................................................................... 40

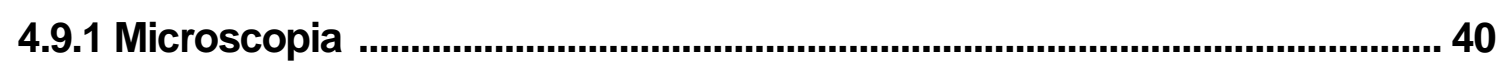

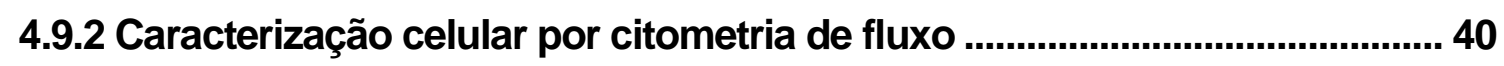

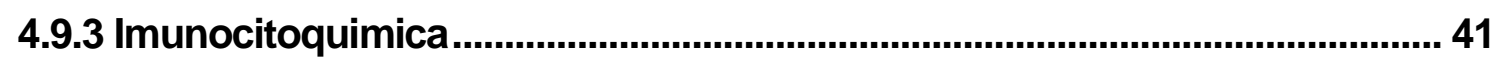

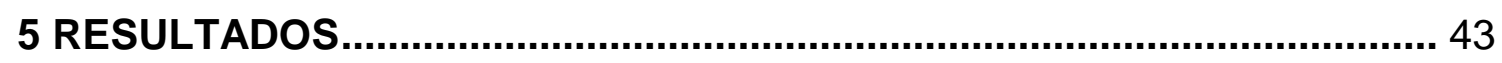

5.1 ANÁLISES MACROSCÓPICAS DO SACO VITELINO E MEMBRANAS

EXTRAEMBRIONÁRIAS 
5.2 ANÁLISES HISTOLÓGICAS E IMUNOHISTOQUIMICA DAS MEMBRANAS

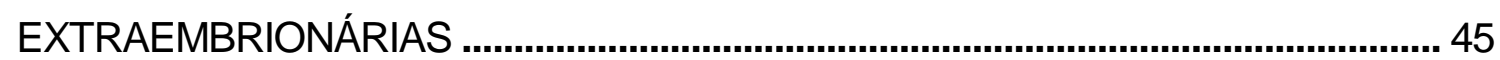

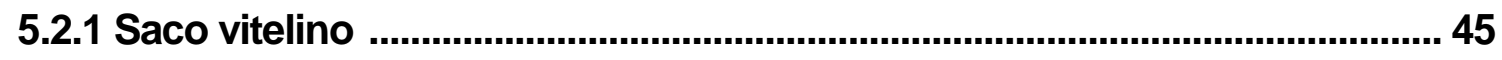

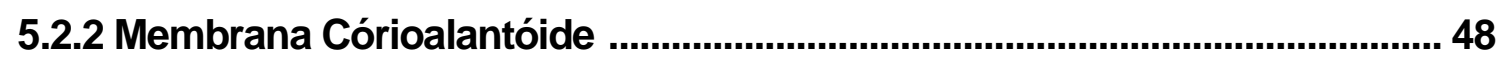

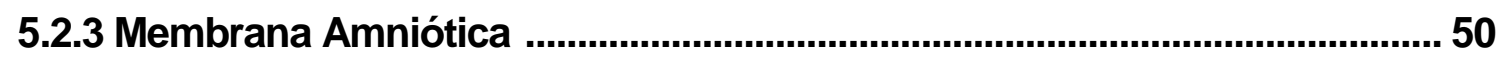

5.3 ANALISES DAS CÉLULAS-TRONCO OBTIDAS DO SACO VITELINO ............. 52

5.3.1 Morfologia das células-tronco ................................................................... 52

5.3.2 Análise da curva de crescimento ........................................................... 53

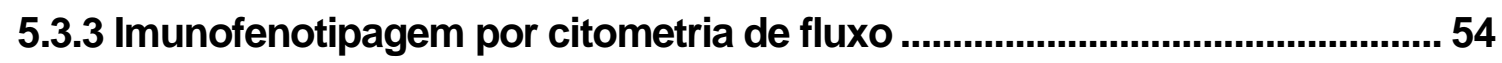

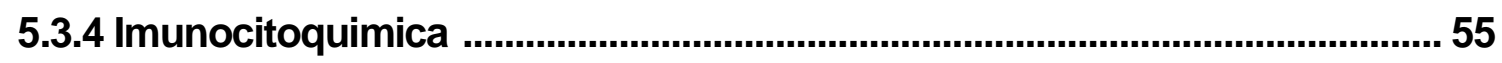

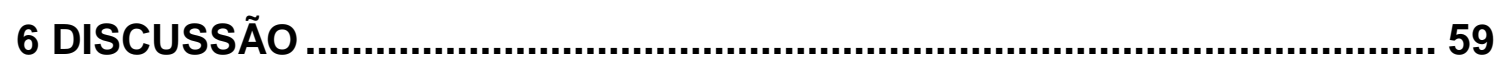

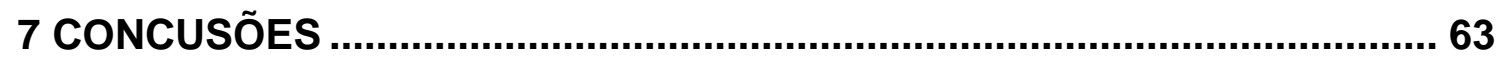

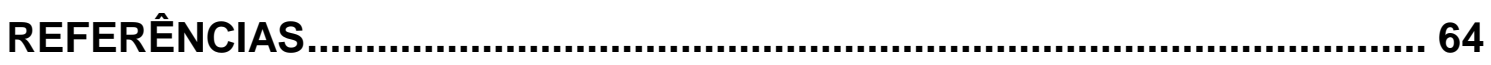




\section{INTRODUÇÃO}

Nos últimos anos, o tema células-tronco tem sido muito discutido, por estas serem capazes de recapitular o desenvolvimento de tecidos embrionários e adultos e reparar injúrias, defeitos congênitos e / ou degenerativos, o que gera uma série de perspectivas benéficas a respeito. Ao mesmo tempo, elas constituem um modelo importante para a compreensão de eventos celulares e moleculares complexos que ocorrem durante o desenvolvimento embrionário primitivo e na progressão de doenças. As propriedades que as tornam únicas são: a capacidade de autorenovação ilimitada acompanhada de alta plasticidade, permitindo que as mesmas se diferenciem em outros tipos celulares, como por exemplo, músculo, células nervosas, células germinativas (CHEN et al.,1999; WEST et al., 2006; ALVEZ et al., 2007).

Contudo, os resultados obtidos em animais ainda não podem ser extrapolados para a espécie humana, haja vista que essas propriedades têm sido demonstradas principalmente em modelos murinos (roedores) ou em outros animais de laboratório, nos quais a adaptação para uso na clínica humana não é viável, especialmente se considerarmos a enorme diferença morfofisiológica e variabilidade genética entre as espécies (SILVA-JUNIOR; BOROJEVIC, 2007).

As primeiras pesquisas descrevendo 0 isolamento de células-tronco embrionárias na espécie suína foram publicadas em 1990 (NOTARIANNI et al., 1990; PIEDRAHITA; ANDERSON; BONDURANT, 1990) e algumas linhagens celulares já foram estabelecidas. Porém, a identificação dos mecanismos regulatórios de pluripotência e a caracterização de condições de cultivo apropriadas proveriam uma visão mais detalhada das necessidades envolvidas no sucesso do estabelecimento de células-tronco embrionárias suínas, juntamente com a padronização das técnicas de cultivo.

Segundo Li et al. (2004), a auto-renovação e a pluripotência das célulastronco embrionárias é regulada por uma complexa rede de eventos, a qual é constituída por uma série de fatores celulares em micro ambientes, uma cadeia de fatores transcricionais e vias de condução de sinais.

O uso da terapia celular por meio de utilização de uma célula ou de um grupo de populações celulares visa restabelecer a estrutura e a função de um tecido 
(SILVA-JUNIOR; BOROJEVIC, 2007). Essa atividade está envolvida em tratamentos de disfunções orgânicas causadas por traumas, doenças, processos degenerativos precoces naturais ou causados por agressão ambiental ou pelo processo degenerativo próprio. Os avanços ocorridos têm impulsionado relações e estudos multidisciplinares que possibilitam a criação de um novo exercício de atuação profissional que estrutura a biotecnologia, bioengenharia e medicina regenerativa.

Estudos com modelos animais têm demonstrado que transplante de células tronco fetais ou células tronco pluripotentes podem ter sucesso no tratamento de muitas doenças crônicas, como Parkinson, diabetes, doenças de medula espinhal, degeneração das células de Purkinje, distrofia muscular, falência do fígado e coração e imperfeições osteogências (HORWITZ, 1999; SORIA et al., 1999; KOBAYASHI, 2000).

Estudos pré-clínicos realizados em suínos são muito relevantes para aplicações em seres humanos, uma vez que sua fisiologia e imunologia são semelhantes, e estes estudos adicionam continuamente evidências sobre a segurança e a eficácia do transplante de células tronco mesenquimais. Vários estudos têm mostrado que um microambiente específico, conhecido como nicho, desempenha um papel muito importante decidindo o fenótipo e diferenciação de células-tronco (STREULI, 1999).

Outra importante caracteristica abordando pesquisas com embriões de mamiferos, focando as células-tronco de embriões suínos, é que estas podem ser exploradas para a produção de animais transgênicos para o uso de doadores de xenotransplantes, e assim diminuir a taxa de reijeição (KIM et al., 2010). 


\section{OBJETIVO}

\subsection{OBJETIVOS GERAIS}

Esse estudo tem como objetivo a obtenção, cultivo e expansão de células de saco vitelino de suínos (Sus scrofa) visando caracterizar estas células quanto ao seu potencial como possível fonte de células-tronco mesenquimais pluripotentes, para futuro uso na terapia celular regenerativa.

\subsection{OBJETIVOS ESPECÍFICOS}

- Analisar morfologicamente e imunohistologicamente as membranas extraembrionárias na idade de 20 e 30 dias de gestação;

- Analisar morfologicamente as células obtidas do saco vitelino de suínos (SVS);

- Estabelecimento e caracterização da cultura celular destas células (SVS); 


\section{REVISÃO DA LITERATURA}

Nas ultimas três décadas houve descobertas nas áreas de biologia celular e biologia do desenvolvimento, que mudaram o pensamento e o modo de entendimento sobre o que é vida. $O$ isolamento e cultivo de células tronco, tanto em camundongos (EVANS; KAUFMAN, 1981) como em humanos (THOMSON et al., 1998) e a criação in vitro, de músculos e células nervosas, através de células tronco (CHEN et al., 1999; WEST et al., 2006), quebra novas barreiras para a medicina regenerativa, como uma renovável fonte de células (WOBUS; BOHELER, 2005). Por se tratar de uma revisão de literatura ampla, esta foi divida em tópicos:

3.1 PLACENTA E MEMBRANAS EXTRA-EMBRIONARIAS: CÓRIO, ÂMNIO, ALANTÓIDE E SACO VITELINO

Durante a gestação, os vertebrados vivíparos desenvolvem um sistema complexo de membranas nutricionais que envolvem o feto. No local de aposição ou de união das membranas fetais com a mucosa uterina é formada a placenta, que é um órgão transitório formado por tecidos maternos e fetais, com a função de transportar substâncias nutritivas do organismo materno para o feto, bem como promover "trocas metabólicas" e desempenhar funções endócrinas quanto à produção de hormônios na manutenção da gestação (LEISER; KAUFMANN, 1994).

Todas as placentas dos mamíferos aumentam a área de contato entre as superfícies materna e fetal através da forma intensa das interdigitações dos tecidos. Quando esta distribuição se prolonga na maior parte da superfície coriônica (LEISER; KAUFMANN, 1994), ou seja, quando as vilosidades distribuem-se regularmente pelo córion, temos a placenta difusa (suíno e equino).

A placenta é um dos órgãos estruturalmente mais complexos. Essa complexidade é promovida, em parte, pela interação dos tecidos de origem materna e fetal, além da presença de uma variedade de camadas intermediárias que se interpõem entre os leitos vasculares materno e fetal (SCWARZE, 1970).

São anexos embrionários o córion, âmnio, alantóide e saco vitelino (Figura 1), 
estas são membranas estruturais diferentes e estão envolvidas no desenvolvimento placentário. O âmnio é uma fina membrana que delimita uma bolsa repleta de liquido - o liquido amniótico que tem a função de proteger o embrião contra choques mecânicos, também é cavidade derivada da divisão (roedores e primatas) ou dobramento (mamíferos) do ectoderma embrionário (LEISER; KAUFMANN, 1994). O alantóide surge de uma evaginação da parte posterior do intestino do embrião. Em embriões de aves e répteis ele atua com uma superfície respiratória, enquanto em mamíferos os seus vasos sanguíneos transportam sangue entre o embrião e placenta. O córion é a membrana extra-embrionária mais externa de aves, répteis e mamíferos, estando envolvido no intercambio gasoso respiratório. Em mamíferos está envolvido com a nutrição e eliminação de resíduos, é uma película delgada que envolve os outros anexos embrionários (WOLPERT et al., 2000). O saco vitelino se desenvolve como uma estrutura anexa do intestino médio embrionário e consiste de uma camada de epitélio endodérmico seguido de um mesênquima fetal vascularizado (LEISER; KAUFMANN, 1994).

Segundo Toniollo e Vicente (1993) as membranas fetais determinam a formação da cavidade amniótica e da cavidade alantoideana, que estão preenchidas por líquidos. O liquido amniótico nos suínos possui coloração amarelada, aspecto transparente e consistência viscosa, já o liquido alantoideano é amarelo-âmbar e com aspecto transparente e consistência aquosa.

Figura 1 - Esquema das membranas extraembrionárias em desenvolvimento

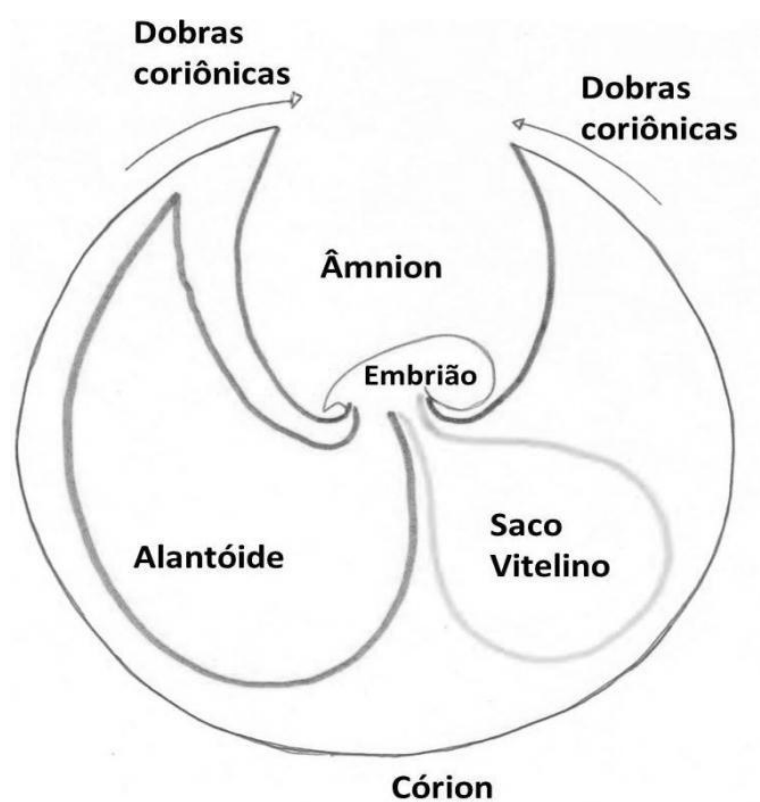

Fonte: Adpt. (SCHLAFER; FISHER; DAVIESI, 2000) 
epitélio coriônico representa a decisiva barreira de trocas materno-fetais (LEISER; KAUFMANN, 1994). Durante a implantação, ó córion é preenchido por um a camada interna de tecido mesenquimatoso que deriva do embrião. Logo em seguida o mesênquima desenvolve seu próprio sistema de capilaziração. A cavidade envolvida pelo córion é denominada exoceloma e contem o embrião, o âmnio, o alantóide e o saco vitelino (ASSIS NETO, 2005).

Por ser responsável pela troca materno-fetal, o córion tem que apresentar uma circulação funcional. Entretanto, é um tecido intrinsecamente avascular, sendo vascularizado exclusivamente por vasos do alantóide (KAUFMANN; BURTON, 1994).

O córion em bovinos reproduz macroscopicamente o formato geral do interior do útero. Apresenta-se relativamente delgado e frágil de coloração esbranquiçada e lisa (BARONE, 1986).

O alantóide corresponde à bexiga urinária extra-embrionária e se desenvolve a partir do intestino grosso embrionário, é caracterizado como um saco extraembrionário formado com camada simples de células pavimentosas que é envolvido por mesênquima extremamente vascularizado (ASSIS NETO, 2005).

O alantóide em ruminantes é um grande saco repleto de liquido ao lado do âmnio (REEVES et al., 1972), e o córion e âmnio não são vascularizados até se fundirem com o alantóide (LATSHAW, 1987; WOODING; FLINT, 1994).

A membrana alantóide cresce cranial e caudalmente ao longo das faces ventral e lateral do embrião bovino, sendo que na $4^{\circ}$ semana de gestação, este ocupa toda a cavidade celômica, estendendo-se entre as membranas fetais (NODEN; DE LAHUNTA, 1990).

Essa estrutura tem o formato de um tubo longo dividido em dois compartimentos, que se comunicam entre si e com úraco. As paredes são delgadas e transparentes, e se distribui irregularmente dentre do córion, justapondo-se a uma das faces do âmnio (MARSHALL, 1952; BARONE, 1986).

Em ovinos o alantóide surge macroscopicamente no $16^{\circ}$ dia de gestação (BRYDEN; EVANS; BINNS, 1972) e em bovinos a membrana acima citada inicia sua

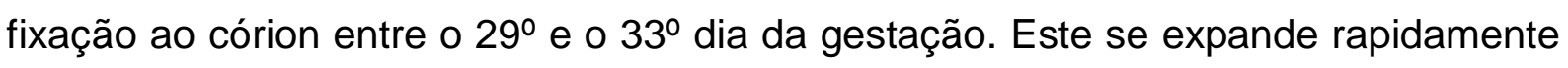
e, com cinco semanas, ocupam ambos os cornos uterinos (LATSHAW, 1987).

A membrana amniótica é responsável pela hidratação do feto, nutrição, lubrificação do canal do parto e proteção mecânica (LEISER; KAUFMANN, 1994). 
âmnio é formado por células epiteliais que apresentam morfologia uniforme e não difere dos outros mamíferos (STEVEN, 1982). As que constituem o epitélio amniótico são pavimentosas, continuas e organizadas, formando um epitélio pavimentoso simples, semelhante ao epitélio do alantóide. O epitélio amniótico esta apoiado em uma camada de tecido conjuntivo embrionário, que constitui 0 mesênquima (ASSIS NETO, 2005).

A parede da cavidade amniótica dos ruminantes é transparente, pouco vascularizada e apresenta uma extensa relação com o córion (SCHARZE, 1970; BARONE, 1986; NODEN; DE LAHUNTA, 1990).

Uma membrana extra-embrionária que desempenha um papel importante para a sobrevivência inicial do embrião em muitas espécies de mamíferos é o saco vitelino, pois esta é a principal fonte de nutrição do embrião durante o período em que a placenta verdadeira ainda não esta completamente formada, sua importância também esta relacionada à hematopoiese (WOLF et al., 2003), síntese protéica, atividade fagocitária, transferência de matérias e também a capacidade de originar células-tronco multipotentes, através de um processo denominado hematopoiese (GALDOS et al., 2010).

A importância do saco vitelino como órgão placentário e hematopoiético é bem conhecida nos roedores (DEREN et al., 1966; HAAR; ACKERMANN, 1971); entretanto, o mesmo não ocorre no caso dos mamíferos domésticos, nos quais as informações são bastante escassas. A sua estrutura, grau de diferenciação, tempo de aparecimento e desaparecimento, e distinção física variam grandemente entre as espécies e são pobremente descritos na literatura (MOSSMAN, 1987).

Em suínos, o saco vitelino persiste por várias semanas até que as membranas corioalantóicas estejam estabelecidas, quando então regride rapidamente e o remanescente é absorvido pelo cordão umbilical do feto (MARRABLE, 1971; TIEDEMANN e MINUTH, 1980; LIWSKA; GRABINSKIBARANOWSKI, 1994).

Nos ruminantes o saco vitelino é funcional durante um curto período de tempo (NODEM; DE LAHUNTA, 1990), porém, suas funções nesta fase são muito importantes, dentre elas destacamos: absorção e digestão de nutrientes maternos, síntese de proteínas, formação da circulação vitelina e secreção intravascular de nutrientes (LATSHAW, 1987; BARON, 2003).

Segundo Mossman (1987) o saco vitelino dos mamíferos é bilaminar no início 
da gestação (fase de blastocisto) e consiste de trofoctoderma e endoderma extraembrionário. Ele se torna trilaminar com a propagação do mesoderma extraembrionário entre o ectoderma e endoderma.

O endoderma do saco vitelino é uma camada formada por células cubóides a colunares que formam dobras que se projetam em direção ao mesênquima, formando uma estrutura composta por colunas de células endodérmicas. Tiedemman e Minuth (1980) relatam que esse este processo ocorre devido à proliferação do endoderma, que em estágios avançados de desenvolvimento pode representar mais de $90 \%$ da massa total do saco vitelino, fazendo com que ele se assemelhe a um órgão quase que parenquimatoso; os canalículos formados pelas dobras do endoderma provavelmente funcionam como um sistema tubular que conduz as substâncias produzidas pela endoderme.

O saco vitelino também mantém o desenvolvimento primário do feto produzindo um espectro de proteínas séricas (TIEDEMANN; MINUTH, 1980; JANZEN; MABLY; TAMAOKI, 1982; YOUNG; KLEIN, 1983; SHI; HOPKINS; THOMPSON, 1985) e funções como sítio de formação de células sangüíneas primárias (LIWSKA; GRABINSKI-BARANOWSKI, 1994; NIIMI; USUDA; SHINZATO, 2002). Tais funções são de particular importância para o suíno, pois, nessa espécie, a formação da placenta é adiada tendo início somente após o $18^{\circ}$ dia de gestação (TALBOT et al., 2007). Dessa forma, o saco vitelino tem a função especializada de manter o desenvolvimento primário do feto até que os suprimentos nutricional e fisiológico sejam assumidos pela formação da placenta corioalantóica e com a conexão desta com o útero, isto é, a placentação (LIWSKA; GRABINSKIBARANOWSKI, 1994; BAVIK; WARD; CHAMBOM, 1996).

Latshaw (1987) e Baron (2003) relatam que o saco vitelino de mamíferos domésticos é inicialmente grande, mas regride quando a placenta permanente se desenvolve.

Para Palis e Yoder (2001) o saco vitelino também é o primeiro local de produção de células sanguíneas no rato e no homem. Células eritrocíticas primitivas originam no saco vitelino e completam sua maturação incluindo enucleação, na circulação sanguínea. Embora diferenças de espécies existam, o aparecimento padrão de célula progenitora hematopoiética no saco vitelino é semelhante no rato e homem. Em ambas as espécies, há uma fase de desenvolvimento nas quais as células sanguíneas vermelhas são produzidas pelos progenitores eritrocíticos do 
saco vitelino.

\subsection{CÉLULAS-TRONCO}

As células-tronco são definidas funcionalmente como células que tem a capacidade de auto-renovação associada a habilidade de gerar diferentes células, ou seja, elas podem gerar células filhas idênticas à mãe (auto-renovação), além de produzir linhagem com potencial mais restrito (células diferenciadas) (MELTON; COWAN, 2004; LI; XIE, 2005).

Com base na sua origem e propriedades biológicas, as células-tronco podem ser classificadas em embrionárias ou adultas. As células-tronco embrionárias são derivadas da camada interna do embrião no estagio de blastocisto e possuem capacidade de dar origem a mais de 200 tipos celulares (ZHANG et al., 2006).

As células-tronco adultas estão presentes em órgãos ou tecidos diferenciados (BARRY; MURPHY, 2004) e são reesposáveis pela manutenção da integridade dos tecidos, pelo reparo diante de lesões e pela remodelação dos tecidos (THEISE et al., 2000; LI; XIE, 2005; ZAGO; COVAS, 2006).

O processo de perda de potencial e ganho de funções especializadas é conhecido por determinação. Neste processo, as células-tronco totipotentes do blastômero "dão lugar" às células multi/pluripotentes das camadas germinativas, as quais, por sua vez, "dão lugar" a progenitores de órgãos em desenvolvimento. A determinação tecidual nas células progenitoras é acompanhada por interações com outros tipos celulares. Por exemplo, a determinação das células primitivas intestinais para fígado (MATSUMOTO et al., 2001) ou pâncreas (LAMMERT; CLEAVE; MELTON, 2001) ocorre em associação como o endotélio de vasos sangüíneos em desenvolvimento. À medida que as células se especializam em tecido, o seu potencial se torna mais limitado e elas finalmente se diferenciam em células terminais (ZHANG et al., 2006).

Fatores de transcrição como Oct-4, Sox-2, e Nanog têm sido usados para expressar os altos níveis de pluripotencia das células e são considerados como marcadores de células-tronco primitivas (RODDA et al., 2005).

Estudos têm demonstrado que a pluripotência das células-tronco tem sido 
fortemente regulado pela Oct-4 funcionando em conjunto com Sox-2 e Nanog no núcleo de uma rede de fator de transcrição, mas a expressão de Oct-4 e Nanog têm sido observadas em células-tronco derivadas de diferentes tecidos adultos, romovendo assim o potencial de diferenciação in vitro de multilinhagens (RALSTON; ROSSANT, 2010).

\subsection{CÉLULAS-TRONCO EMBRIONÁRIAS SUÍNAS}

Linhagens de células-tronco embrionárias foram relatadas em várias espécies como ratos (EVANS; KAUFMAN, 1981), bovinos (STRELCHENKO, 1996), coelho (GRAVES; MOREADITH, 1993), primatas (THOMSON et al., 1995), camundongo (IANNACCONE et al., 1994), hamster (DOESTSHMAN; DOETSHMAN; WILLIAMS; MAEDA, 1988), humanos (THOMSON et al., 1998) e suinos (WHEELER, 1994).

Estudos pré-clínicos realizados em suínos são muito relevantes para aplicações em seres humanos e adicionar continuamente as evidências sobre a segurança ea eficácia do transplante de células tronco mesenquimais. Vários estudos têm mostrado que um microambiente específico, conhecido como nicho, desempenha um papel muito importante decidindo o fenótipo e diferenciação de células-tronco (STREULI, 1999).

Sob ótimas condições, as células da massa interna do blastocisto préimplantado são capazes de proliferar indefinidamente (EVANS; KAUFMAN, 1981), assim como, sob condições de indução, podem sofrer determinação e se diferenciar em outros tipos teciduais. Por outro lado, após a formação das camadas germinativas, a maioria das células progenitoras somáticas tem vida útil limitada e exibem redução do potencial de diferenciação à medida que órgãos maduros são gerados (MEROK; SHERLEY, 2001).

Os primeiros informes descrevendo o isolamento de células-tronco na espécie suína datam de 1990 (NOTARIANNI et al., 1990; PIEDRAHITA; ANDERSON; BONDURANT, 1990). Embriões foram produzidos in vitro por lavagem uterina entre o $7^{\circ}$ - 10ำ dia de gestação, quando os blastocistos já estavam implantados. Nessa época, procedimentos imunocirúrgicos para isolar a massa interna eram raramente empregados (PIEDRAHITA; ANDERSON; BONDURANT, 1990) sendo o cultivo do 
embrião inteiro o método mais comum (STROJEK et al., 1990). As linhagens celulares eram cultivadas e propagadas em células fibroblásticas embrionárias murinas comumente utilizadas como camada nutridora em cultivo de células-tronco de camundongos (BREVINI et al., 2007).

A morfologia foi o principal critério utilizado para definir tais células. A maioria das colônias foi descrita como células-tronco quando as células eram pequenas e arredondadas, de núcleo grande e com um ou dois nucléolos proeminentes. Junto às mesmas, foi encontrado um outro tipo celular com aparência epitelial, cuboidal, que quando estavam para confluir, tendiam a formar estruturas remanescentes de camada epitelial (PIEDRAHITA; ANDERSON; BONDURANT, 1990). Tais critérios morfológicos se tornaram contraditórios ao considerar parâmetros como autorenovação e pluripotência. De fato, segundo Talbot et al. (1993), as células de aparência epitelial estão aptas a se replicar por um maior número de passagens que as linhagens de células-tronco. Além disso, essas células têm a habilidade de formar corpos embrionários se cultivadas em suspensão, ao contrário das células-tronco que não demonstram sinais de diferenciação mesmo após 30 dias sob as mesmas condições de cultivo. A correlação direta entre morfologia e potencial de replicação/diferenciação pode ser extremamente complicada e a necessidade por marcadores celulares e moleculares confiáveis é evidente, pois, tais marcadores são pré-requisito para definir o estágio de uma célula e relacioná-lo a moléculas expressas pelo epiblasto in vivo (BREVINI et al., 2007). O primeiro passo importante são os dados obtidos por Talbot et al. (1993), os quais demonstraram que a fosfatase alcalina é um marcador confiável para células-tronco indiferenciadas no suíno e no ovino, seguido pela demonstração da expressão estágio-específica de antígeno embrionário - 1 (WIANNY; PERREAU; HOCHEREAU DE REVIERS, 1997) e pela perda de expressão da laminina ou de filamentos intermediários como vimentina e citoqueratinas $8 / 18$, que estão ausentes na massa celular interna e no epiblasto, mas são detectáveis quando a diferenciação ocorre (PIEDRAHITA; ANDERSON; BONDURANT, 1990; MOORE; PIEDRAHITA, 1997). 


\subsection{CÉLULAS-TRONCO MESENQUIMAIS}

A grande capacidade e potencial de diferenciação das células-tronco mesenquimais (CTMs), a possibilidade de enxerto, seus efeitos imunossupressores e sua expansão em cultura levaram ao aumento do interesse clínico relativo ao uso destas células, através de infusão intravenosa ou administração dirigida ao local de interesse, em numerosas situações patológicas (BYDLOWSKI et al., 2009).

Como proposto pelo comitê de Células-tronco Mesenquimais da Sociedade Internacional de Terapia Celular, as células-tronco mesenquimais humanas são definidas como CD105, CD73 e CD90 positivos (expressão em torno de 90\%) e negativas para CD45, CD34, CD14 ou CD11b, CD79a, ou CD19 e HLA. O marcador de superfície celular STRO-1 é considerado o melhor marcador para células-tronco mesênquimais (KOLF; CHO; TUAN, 2007), porém não é exclusiva para esse tipo celular ainda, sua expressão não é mantida durante sucessivas passagens em cultivo de células-tronco de equinos (LACONO et al., 2010).

Células-tronco mesenquimais (CTMs) são definidas como células-tronco multipotentes que podem se diferenciar em vários tipos de células in vivo e in vitro em condições controladas (VALENTINI et al., 2010), essas celulas tronco (CTMs) podem ser isoladas a partir de vários órgãos do organismo, como por exemplo: medula óssea tecido adiposo, membrana sinovial, músculos, derme, dente decíduo, cordão umbilical, placenta, fígado, baço e timo (MEIRELLES; CHAGASTELLES; NARDI, 2006).

Após o seu isolamento in vitro, as células-tronco mesenquimais mostram uma capacidade de diferenciação em várias linhagens mesenquimais (LEE et al., 2010) e em vários tecidos quando induzidas após a utilização de culturas adequadas. As CTMs diferenciam em osteoblastos (JAISWAL et al., 1997; LONG, 2001;), adipócitos, condrócitos, tenócitos, células musculares, cardiomiócitos e células do estroma de sustentação da hematopoiese, (PROCKOP, 1997; PITTENGER et al., 1999; CAPLAN, 2005).

Outra característica das CTMs é que quando cultivadas em baixa densidade a adesão e a formação de colônias é rápida. Presume-se que estas colônias sejam derivadas de uma única célula precursora (DEANS; MOSELEY, 2000).

A microscopia de luz mostra que as células-tronco mesenquimais possuem 
formato fibroblastóides alongados, fusiformes e potiagudas, com núcleos eucromáticos, ovais, grandes e centrais e com citoplasma abundante (TAGAMI et al., 2003).

Autores como Schauwer et al. (2011) relatam que a expansão de célulastronco mesenquimais (CTM) de diferentes origens (celulas de medula ossea, sangue periférico, anexos embrionários, entre outros), tem sido muito estudada pelo fato de se diferenciarem em varias linhagens, e representam uma população promissora para as terapias celulares com base em medicina veterinária. Há ainda poucas informações sobre as origens das CTMs, uma teoria é a origem neuroectodermal, a partir de células neuroepiteliais SOX1 (TAKASHINMA; ERA; NAKAO, 2007).

Embora anticorpos para vários antígenos de superfície possam ser usados para reconhecer as CTM, não existem marcadores específicos para identificá-las, onde estudos realizados em culturas de CTM não clonais mostram certo perfil característico: CD34-, CD45-, CD14-, CD13+, CD29+, CD44+, CD49a+, CD63+, CD90+, CD105+, CD106+, CD146+, CD166+ (FILSHIE et al., 1998; BARRY et al. 1999; GRONTHOS et al., 1999; STEWART et al., 2003; ZANNETTINO et al., 2003; BIANCO; ROBEY; SIMMONS, 2008). Esse fenótipo pode ser modulado em cultura, e não reflete o fenótipo in vivo. Grande parte desses marcadores é expresso em diferentes níveis em linhagens de fibroblastos, que não se comportam como as células estromais da medula óssea tanto in vivo quanto in vitro (BIANCO et al., 2006). Na busca de marcadores para CTM, Jones et al., (2006) identificaram o marcador Stro-1 uniforme e expresso na população de CTM oriundas da medula óssea.

As células estromais expressam também uma série de fatores proangiogênicos, como a Angiopoetina-1 (Ang-1), o fator de crescimento endotelial vascular (VEGF), fator de crescimento derivado de plaquetas (PDGF), fator de crescimento de fibroblastos 2 (FGF-2), FGF-7, citocinas (II-6 e TNF-a) e o ativador do plasminogênio tecidual (PAt). Além de promover a angiogênese, as CTM induzem a expressão de proteínas de junção e um aumento na integridade microvascular (ZACHAREK et al., 2007).

Devido à ausência atual de marcadores prospectivos para o isolamento e caracterização das CTM, sua definição se baseia em propriedades físicas, fenotípicas e funcionais (DOMINICI et al., 2006). 


\subsection{REAÇÃO DE IMUNOHISTOQUIMICA PARA DETECÇÃO DE CITOQUERATINA E VEGF}

Células-tronco pluripotentes derivadas de diversos tecidos tais como fígado, sangue, e entre outros, são isoladas tanto de fetos, como de animais adultos, demonstrando a capacidade de se propagar e de se diferenciar em diversos tipos celulares in vitro (ZHANG et al., 2006). Existe um grande interesse na identificação de fatores e sinais que governam o início da diferenciação celular e no esclarecimento de como os mesmos provêm os mecanismos moleculares envolvidos no estabelecimento desse processo.

Em camundongos, o endoderma primitivo pode induzir a diferenciação hematopoiética a partir do epiblasto anterior, tecido o qual não tem a capacidade de gerar células hematopoiéticas. A expansão e/ou diferenciação de cada progenitor em animais é obtida pela sinalização do VEGF, TGF- $\beta 1$ e activina A (PARK; SHIN; KIM, 2007), enquanto em embriões humanos, a interação do VEGF com o seu receptor KDR está relacionada à sobrevivência, proliferação e migração do hemangioblasto (WANG et al., 2004).

Entre os principais reguladores pro-angiogênicos, estão o fator de crescimento celular endotelial vascular (VEGF) e o fator de crescimento de fibroblasto (FGF). O VEGF emerge como o fator de crescimento mais importante, sendo sintetizado e secretado por células mesenquimais, principalmente por fibroblastos e macrófagos. Caracteriza-se como um potente indutor da vasculogênese e tem um papel central na angiogênese tumoral, inflamação crônica e cicatrização de feridas. O FGF pode ser secretado por macrófagos, mastócitos, células endoteliais e fibroblastos. Apresenta-se de duas formas: FGF-1 ou aFGF (acido) e FGF-2 ou bFGF (básico), ambos com o papel semelhante de induzirem a liberação do VEGF, potencializando, portanto, o mecanismo da angiogênese (NETTO et al., 2008; POON; FAN; WONG, 2001)

As citoqueratinas (CK) são constituintes do citoesqueleto das células epiteliais, sendo assim, também denominadas queratinas epiteliais ou queratinas moles (MACHADO; FIGUEIREDO, 1996; LANGBEIN et a., 1999).

Embora as queratinas possam ser distinguidas imunologicamente, anticorpos produzidos contra queratina da epiderme humana e queratina da pele de bovinos 
mostram reações cruzadas com uma variedade de células epiteliais da respectiva espécie e entre outras espécies, incluindo o homem, coelho, rato, camundongo, bovinos e anfíbios (MACHADO; FIGUEIREDO, 1996).

De maneira semelhante, a vimentina é utilizada no diagnóstico de célulasmesênquimais, porém o grande número de citoqueratinas auxilia seu uso no diagnóstico das neoplasias epitelial sendo mais amplo do que no caso da vimentina (ALMEIDA-JR, 2004). 


\section{MATERIAL E MÉTODO}

Os procedimentos realizados nessa pesquisa apresentam-se subdivididos em:

\subsection{LABORATÓRIO}

O presente estudo foi realizado no setor de Anatomia dos Animais Domésticos e Silvestres da Faculdade de Medicina Veterinária e Zootecnia da Universidade de São Paulo, foram utilizados os laboratórios de histologia e o laboratório de CélulasTronco - LCT - do setor de Anatomia, VCI, FMVZ-USP.

\subsection{ANIMAIS}

Foram utilizados embriões com 20 dias $(n=15)$ e embriões com 30 dias $(n=5)$. A coleta foi feita a partir do abate das fêmeas de suínos, raça Landrace, gestantes previamente inseminadas (20 dias) e resultantes por monta natural (30 dias). Proveniente da suinocultura Grupo Cabo Verde localizada na cidade de Monte Santo de Minas e da suinocultura Umburama localizada na cidade de Atibaia.

\subsection{COLETA DE EMBRIÕES E MEMBRANAS DE SUINOS}

O material coletado foi transportado para o Laboratório de Células tronco do setor de Anatomia dos Animais Domésticos e Silvestres da Faculdade de Medicina Veterinária e Zootecnia de São Paulo-USP, onde os úteros foram abertos cirurgicamente para a retirada dos embriões em fluxo laminar sob condições assépticas (em solução fisiológica estéril). 


\subsection{MICROSCOPIA DE LUZ DAS MEMBRANAS}

As membranas fetais foram colocadas em solução fixadora de paraformaldeídeo $4 \%$. Após fixação, o material foi desidratado em uma série de etanóis em concentrações crescentes (70 a 100\%) e diafanizado em xilol, seguido de inclusão em parafina (BEHMER, 1976; TOLOSA et al., 2003). Foram obtidos cortes seriados com espessura de $5 \mu \mathrm{m}$ em um micrótomo (RM2165, Leica, Nussloch, Alemanha), e submetidos a colorações segundo protocolo de coloração de Hematoxilina/Eosina e para posterior descrição.

PROTOCOLO DE HEMATOXILINA E EOSINA

$\begin{array}{ll}\text { XILOL I } & 5 \mathrm{MIN} \\ \text { XILOL II } & 5 \mathrm{MIN} \\ \text { ALCOOL } 100 \% & 5 \mathrm{MIN} \\ \text { ALCOOL } 95 \% & 5 \mathrm{MIN} \\ \text { ALCOOL } 90 \% & 5 \mathrm{MIN} \\ \text { ALCOOL } 70 \% & 5 \mathrm{MIN} \\ \text { AGUA CORRENTE } & 10 \mathrm{MIN} \\ \text { HEMATOXILINA } & 3 \mathrm{MIN} \\ \text { AGUA CORRENTE } & 10 \mathrm{MIN} \\ \text { EOSINA } & 30 \mathrm{SEG} \\ \text { ALCOOL } 70 \% & 5 \mathrm{MIN} \\ \text { ALCOOL } 90 \% & 5 \mathrm{MIN} \\ \text { ALCOOL } 100 \% & 3 \mathrm{MIN} \\ \text { ALCOOL } 100 \% & 3 \mathrm{MIN} \\ \text { XILOL I } & 5 \mathrm{MIN} \\ \text { XILOL II } & 5 \mathrm{MIN}\end{array}$

A documentação fotográfica macroscópica foi feita através de uma câmera digital (MVC-CD500, Nikon, Tokyo, Japão) e microscópica através de um fotomicroscópio (DM 2000, Leica, Nussloch, Alemanha). A nomeclatura utilizada foi referida conforme International Commitee on Veterinary Gross Anatomical 
Nomenclature, International Commitee on Veterinary Gross Histological Nomenclature e International Commitee on Veterinary Embryological Nomenclature.

\subsection{IMUNOHISTOQUIMICA: DETECÇÃO DE CITOQUERATINA E VEGF}

Para a realização do protocolo de imunohistoquímica foram utilizadas membranas de embriões de 20 e 30 dias (fixados em formaldeídeo a 10\% tamponado, $\mathrm{pH} 7,4)$. As membranas foram processadas rotineiramente através de inclusão em parafina (BEHMER, 1976; TOLOSA et al., 2003). Em seguida os blocos foram cortados sequencialmente e colocados em lâminas previamente silanizadas, com 3 cortes por lâmina sendo um para controle negativo.

O protocolo utilizado para a técnica de imunohistoquímica foi o convencional:

\section{PROTOCOLO DE IMUNO-HISTOQUÍMICA}

\section{Anticorpos: VEGF e CITOQUERANA}

$1^{\circ}$ DIA

- DESPARAFINIZAÇÃO

- Xilol I 10min

- Xilol II 10min

- Álcool + Xilol 3min

- Álcool 100\% 3min

- Álcool 90\% 3min

- Álcool 70\% 3min

- Água Destilada 3min

- Desmascaramento em tampão citrato $1 x(\mathrm{pH}$ 6.0) diluído em PBS no forno micro-ondas (3 x3min)

- Deixar esfriar em temperatura ambiente por $\pm 30 \mathrm{~min}$ 
- Bloqueio da peroxidase em solução $\mathrm{H}_{2} \mathrm{O}_{2} 3 \%$, diluído em metanol (5min)escuro.

- Lavagem em PBS $1 \mathrm{x}+$ Tween ( 3 x 5min)

- $\mathrm{TBN}-5$ min - escuro

- Lavagem em PBS $1 x+$ Tween ( 3 x 5min)

- Incubação das lâminas com Anticorpo Primário diluído em PBS 1x (sem tween). Verificar a diluição de cada anticorpo. As lâminas devem ficar overnight, em câmara úmida (geladeira $4^{\circ} \mathrm{C}$ )

20 DIA

- Lavagens em PBS $1 x+$ Tween (3 x 5min)

- Incubação com advance HRPlink em T.A. (30min) - em câmara úmida

- Lavagens em PBS $1 x+$ Tween ( 3 x 5min)

- Incubação com Advance HRP Enzime em T.A. (30min) - em câmara úmida

- Lavagens em PBS $1 x+$ Tween (3 x 5min)

- Revelação com DAB (1 mL de DAB/1 gota de cromógeno). Verificar na hora a reação (fica marrom). Quando escurecer parar a reação

- Lavagens em PBS $1 x+$ Tween ( 3 x 5min)

- Coloração de fundo com Hematoxilina de Harris ( $3-5$ segundos)

- Água destilada (5 seg)

- Água amoniacal (100 mL de H2O destilada/ 500 $\mu \mathrm{L}$ hidróxido de amônio - a mesma solução pode ser usada $3 x)-(3-5$ min)

- Água destilada (5 seg.)

- DIAFINIZAÇÃo

- Álcool 70\% 3min

- Álcool 90\% 3min

- Álcool 100\% 3min

- Álcool + Xilol 3min

- Xilol I 10min

- Xilol II 10min

* Montar lâminas com Permount 


\subsection{COLETA DE CÉLULAS DE SACO VITELINO}

A coleta do saco vitelino dos embriões com idades gestacionais de 20 e 30 dias ocorreu sob condições assépticas no laboratório de Células Tronco da FMVZUSP. Para a obtenção das amostras, foi realizada uma incisão cirúrgica no saco gestacional, a fim de promover a exposição dos embriões, bem como os anexos fetais. Inicialmente foram separadas as membranas fetais, com o objetivo de isolar o saco vitelino, o qual foi coletado e acondicionado em placas de petri com solução de PBS-L (Phosphatase Buffer Solution Livre de Cálcio e Magnésio). Seguido este procedimento, as amostras acondicionadas nas placas de petri, foram levadas para dentro do fluxo laminar, de forma que os materiais utilizados, a superfície de contato e o ambiente estejam esterilizados reduzindo assim as chances de qualquer tipo de contaminação das amostras do meio de cultura.

\subsection{ESTABELECIMENTO DA LINHAGEM DE CÉLULAS DO SACO VITELINO}

\subsubsection{Protocolo de cultivo celular para o saco vitelino}

Os embriões nas idades de 20 e 30 dias, foram coletados em solução PBS estéril gelado, os embriões, juntamente com as membranas fetais, foram posteriormente transferidos em condições assépticas para uma placa de petri no interior do fluxo laminar, onde o saco vitelino foi separado do mesmo. Em seguida o saco vitelino foi transferido para o interior de um tubo falcon, onde foi digerido enzimaticamente em $1 \mathrm{ml}$ de tripsina $2,5 \%$ a $37^{\circ} \mathrm{C}$ por 5 minutos, em banho maria, com agitação periódica. Para a interrupção da digestão enzimática, a ação da tripsina foi inativada, acrescendo à solução $1 \mathrm{ml}$ de Dulbeco's Modified Eagle Médium (D-MEM) suplementado com $15 \%$ de soro fetal bovino inativado a $56^{\circ} \mathrm{C}$ por 30 minutos, $2 \%$ de L-Glutamina $3 \%, 5 \%$ de HEPES $280 \mathrm{mM}, 0,5 \%$ de bicarbonato de sódio 7,5\% $\left(\mathrm{NaHCO}_{3}\right)$ e solução antibiótico e antifúngico (10.000 UI de penicilina, $10 \mathrm{mg}$ de estreptomicina e $25 \mu \mathrm{g}$ de anfoterricina B). As células foram cultivadas em 
placas de 6 poços com $4 \mathrm{ml}$ de meio de cultivo por cavidade em estufa de $5 \%$ de $\mathrm{CO}_{2}$ e temperatura de $37^{\circ} \mathrm{C}$.

\subsubsection{Dissociação enzimática das células aderentes: Repique celular}

As células derivadas do saco vitelino, por apresentarem característica de adesão ao substrato, necessitam sofrer desagregação enzimática, à medida que atingem confluência (80\%). A dissociação desta teve inicio com a retirada do meio de cultivo existente na garrafa; estas foram lavadas com PBS-L, para a retirada de todo o resíduo do meio de cultivo. Posteriormente foi adicionado $1 \mathrm{ml}$ de tripsina a $0,25 \%$ (Tryple Express - Gibco) permanecendo encubada por 5 minutos a $37^{\circ} \mathrm{C}$.

Após este período foi adicionado $5 \mathrm{ml}$ de meio de cultivo suplementado com SFB, para a inativação da tripsina; toda suspensão celular foi aspirada e transferida para um tubo tipo falcon com $5 \mathrm{ml}$ de meio de cultivo. Seguidamente os tubos foram centrifugados por 1000rpm há 5 minutos. O "pellet" resultante da centrifugação foi ressuspendido em $1 \mathrm{ml}$ de meio de cultura, para a contagem celular, sendo posteriormente transferidos para garrafas de cultivo com meio de cultivo. As células foram novamente incubadas sob as mesmas condições de cultivo a $37,0^{\circ} \mathrm{C}$ com umidade relativa próxima de $100 \%$ e atmosfera gasosa de $5 \%$ de $\mathrm{CO}_{2}$.

\subsubsection{Ensaio de concentração e viabilidade celular}

A concentração celular foi determinada através do método de exclusão pelo Trypan Blue. Após adição e homogeneização de $20 \mu$ da suspensão celular em $20 \mu l$ de solução de Trypan Blue. Uma alíquota de $15 \mu l$ foi disposta em um hematocitômetro e observada ao microscópio óptico. A concentração celular foi determinada pela contagem das células em 5 campos diagonais, sendo o total de células vivas multiplicado por 5 (25 campos), por 2 (diluição do corante) e por $10^{4}$ (profundidade da câmara e correção por $\mathrm{ml}$ ), enquanto a viabilidade da amostra foi determinada pela relação entre a quantidade de células vivas (não coradas). 


\subsubsection{Avaliação do crescimento celular: curva de crescimento}

Foi realizada a primeira contagem de células a partir do primeiro repique celular, quando as células atingiram aproximadamente $70 \%$ de confluência. A cada 3 dias as células foram tripsinizadas, contadas e plaqueadas. Utilizando-se a câmara hemocitométrica (Neubauer). A partir do número de células contadas em cada tubo, calculou-se a média diária que foi utilizada para elaboração da curva de crescimento. Os tubos utilizados no presente estudo foram semeados no mesmo dia na concentração de $1 \times 10^{5}$ céls $/ \mathrm{ml}$, sem troca de meio durante os dias de contagem.

\subsection{CONGELAMENTO E DESCONGELAMENTO CELULAR}

A cultura de células provenientes do cultivo do tecido vitelínico sofreu desagregação enzimática com tripsina á 0,25\%, o qual foi igualmente descrito anteriormente. O "pellet" celular foi ressuspendido com meio de congelamento. $\mathrm{O}$ meio utilizado é composto por $45 \%$ de DMEM-H, suplementado com $45 \%$ de SFBCripton, $10 \%$ de DMSO e $1 \%$ estreptomicina/penicilina, sendo posteriormente distribuídas em criotubos ( $1 \mathrm{ml}$ para cada criotubo); os criotubos permaneceram em isopor com gelo triturado, durante todo o processamento da amostra.

Seguido este procedimento, os criotubos com meio de congelamento, passaram por um protocolo: 30 minutos a $-4^{\circ} \mathrm{C}, 4$ horas a uma temperatura de $-20^{\circ} \mathrm{C}$, 12 horas em temperatura a $-40^{\circ} \mathrm{C}$ para depois as amostras serem transferidas para um tambor de nitrogênio líquido, onde permanecerão armazenadas a uma temperatura de $-196^{\circ} \mathrm{C}$.

Para o descongelamento celular, os criotubos foram retirados cuidadosamente do tambor de nitrogênio líquido, e descongelados em banho maria á temperatura de $37^{\circ} \mathrm{C}$. Em seguida as células foram transferidas para tubos tipo falcon e adicionados meio de cultivo com $10 \%$ de SFB. As amostras foram centrifugadas a 1000rpm por 5 minutos. O sobrenadante foi descartado, e o "pellet" ressuspendido em $5 \mathrm{ml}$ de meio de cultivo suplementado com 10\% SFB, e consequentemente transferido para garrafas de cultivo, com o meio de cultivo 
celular. As garrafas foram acondicionadas na estufa a $37,0^{\circ} \mathrm{C}$ com umidade relativa próxima de $100 \%$ e atmosfera gasosa de $5 \%$ de $\mathrm{CO}_{2}$.

\subsection{MORFOLÓGICA CELULAR}

\subsubsection{Microscopia}

A morfologia microscópica das células derivadas do cultivo foram fotografadas e avaliadas, periodicamente através do microscópio invertido NIKON ECLIPSE TS100. Desta forma foi acompanhado todo o desenvolvimento morfológico durante o crescimento e proliferação celular em cultura.

\subsubsection{Caracterização celular por citometria de fluxo}

Esta técnica permite a identificação e quantificação em células e suspensão. As células da amostra foram marcadas com anticorpos monoclonais específicos ligados a fluorocromos, que permitem a identificação e a quantificação de células pelo tamanho, granulosidade e intensidade de fluorescência, sendo de grande importância para a identificação de populações de células hematopoiéticas.

Foram utilizados marcadores celulares para identificação das células provenientes do saco vitelino, onde estas células foram avaliadas pelas expressões de anticorpos específicos que foram convenientes para o presente estudo (dados das aquisições em anexo).

Após o crescimento e expansão celular, as células em cultura foram tripsinizadas e inativadas com soro fetal bovino, colocada em tubos de $15 \mathrm{~mL}$ em câmara de fluxo laminar previamente esterilizada com álcool 70\% e UV durante 20 minutos. Em seguida o material foi centrifugado à 1500rpm durante 10 minutos para a formação do precipitado celular. Após a centrifugação, foi descartado o sobrenadante e ressuspendido em $5 \mathrm{~mL}$ de solução salina $0,9 \%$ para lavagem, 
centrifugado à 1500RPM durante 10 minutos. Após a centrifugação foi descartado novamente o sobrenadante e acrescentado o tampão FACs Flow, a suspensão foi transferida para tubos de citometria, e adicionados os anticorpos CD105, Nanog, CD45 e Oct-4. e incubados por 15 minutos a $4^{\circ} \mathrm{C}$. As analises de expressão foram realizadas em Citômetro de Fluxo FACSCalibur em 10.000 eventos, e as aquisições analisadas pelo programa Win Mdi 2.8. A expressão de marcadores foi determinada pela comparação com um isotipo controle marcado com o fluorocromo FITC inespecífico.

Para a avaliação da expressão de Oct3/4, as células foram permeabilizadas previamente com $10 \mu \mathrm{l}$ de Triton X-100 (0,1\%) por 30 minutos antes da adição dos anticorpos primários específicos.

Após o crescimento e expansão das culturas, as células de saco vitelino foram incubadas com os seguintes marcadores: CD105 (marcador de endoglina, angiogênico, endotelial), CD45 (marcador de células hematopoéticas), Nanog e Oct4 (marcadores de células-tronco embrionárias e germinativas).

\subsubsection{Caracterização celular por imunocitoquimica}

Foram plaqueadas $1 \times 10^{4}$ células em placas de cultivo com 24 poços de $3 \mathrm{~mm}$ de diâmetro cada, os quais possuíam uma lamínula de vidro. Após 48 horas, quando as células atingiram a confluência de $70-80 \%$, todo o meio de cultivo foi retirado e as células lavadas com PBS por 2 vezes de 5 minutos. Posteriormente, as células foram fixadas em paraformaldeído $4 \%$ por 30 minutos. Em seguida foram lavadas em solução de TBS (Tampão Salino de Tris) por 2 vezes de 5 minutos para retirar o fixador.

Para as amostras nas quais seria adicionado anticorpo com marcação nuclear conhecida, foi realizada a permeabilização da membrana celular através da adição de Triton a 0,1\% em TBS até cobrir toda a superfície da lamínula por 10 minutos em temperatura ambiente. Posteriormente, as células foram novamente lavadas 2 vezes com solução de TBS por 5 minutos.

Em seguida, para evitar reações inespecíficas, foi utilizado solução de $5 \%$ de soro fetal bovino (SFB) em TBS por 1 hora em temperatura ambiente (500 $\mu \mathrm{L} /$ poço) 
em todas as amostras.

Após este período, as células foram incubadas "overnight" a $4^{\circ} \mathrm{C} \mathrm{com}$ os anticorpos primários: Oct-4 (C-10, sc5279, Santa Cruz Biotechnology, Inc, Europe), Citoqueratina 18 (RGE53, sc-32329, Santa Cruz Biotechnology, Inc, Europe), Vimentina (0.N.602, sc-73259, Santa Cruz Biotechnology, Inc, Europe), VEGF (Clone VG1, M7273, DakoCytomation, CA, USA), Stro-1 (sc-47733, Santa Cruz Biotechnology, Inc, Europe), B-tubulina (2146, Cell Signaling Technology, Danvers, MA, USA), PCNA-3 (clone PC10; sc-56, Santa Cruz Biotechnology, Inc, Europe), CD-117 (c-Kit, SCF-Receptor Ab-6, RB-1518-R7, Thermo Scientific, Lab Vision Corporation, Fremont, CA, USA), CD-105 (2Q1707, sc-71042, Santa Cruz Biotechnology, Inc, Europe), CD-90 (Thy-1, aTHy-1A1, Santa Cruz Biotechnology, Inc, Europe) diluídos em PBS na concentração de 1: 50.

Passado este período, as células foram lavadas com TBS por 3 vezes por um período de 5 minutos cada. Em seguida, as células foram incubadas com anticorpo secundário anti-rabbit conjugado com Texas-Red, anti-goat conjugado com FITC (F0479, DakoCytomation, CA, USA) ou anti-mouse IgG conjugado com FITC (AP308F, Chemicon International, Temecula, CA, USA) na diluição de 1:100 por uma hora em câmara escura. Em seguida, as células foram novamente lavadas com TBS por 3 vezes de 5 minutos, seguida por uma lavagem em água destilada, sendo as lâminas posteriormente montadas com o kit de montagem para fluorescência Vectashield com DAPI ( $\mathrm{H}-1200$, Vector Laboratories, Inc., Burlingame, CA, EUA). Para visualizar as reações foi utilizado o microscópio de fluorescência LSM 510 (Carl Zeiss Microscopy, Jena, Germany) nas objetivas de 20x e 40x. 


\section{RESULTADOS}

\subsection{ANÁLISE MACROSCÓPICA DAS MEMBRANAS-EXTRAEMBRIONÁRIAS}

$\mathrm{Na}$ idade de 20 dias de gestação notou-se a presença de diferentes fases de desenvolvimentos nos embriões, onde alguns se apresentavam um pouco mais desenvolvido que outros (Figura 2).

Figura 2- Fotomacrografia de embriões suínos com gestação de 20 dias, notar a diferença de desenvolvimento embrionário em uma mesma gestação. Barra 500 $\mu$ m.

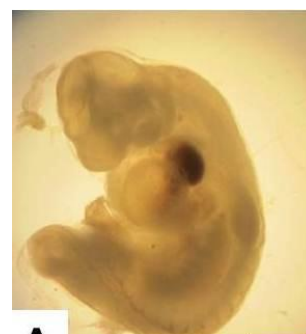

A

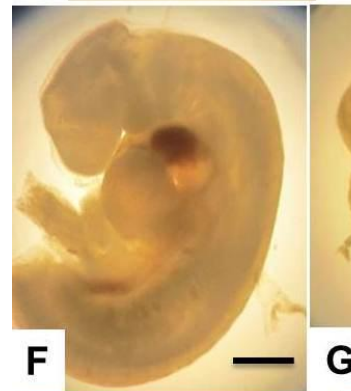

B
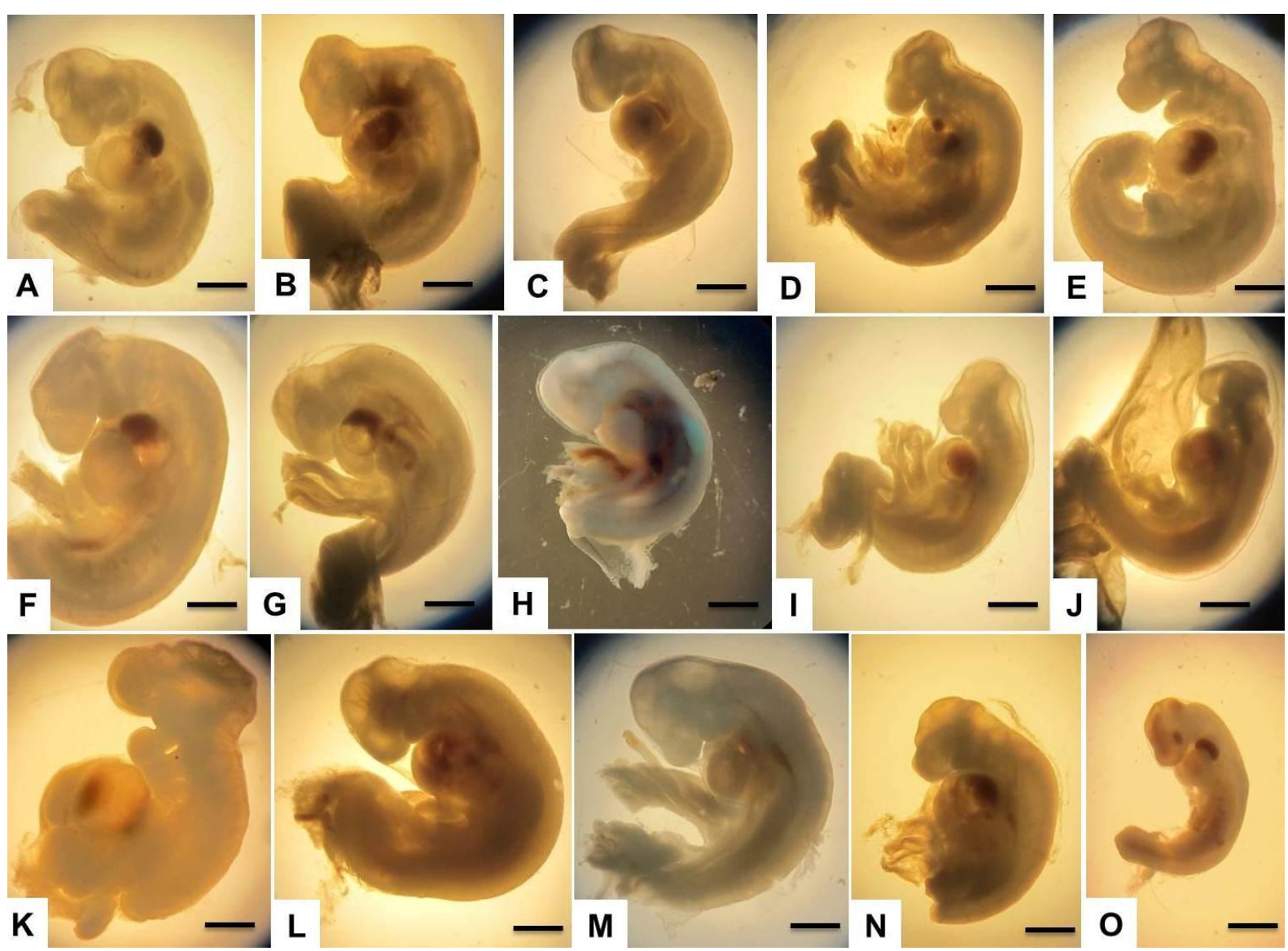

M
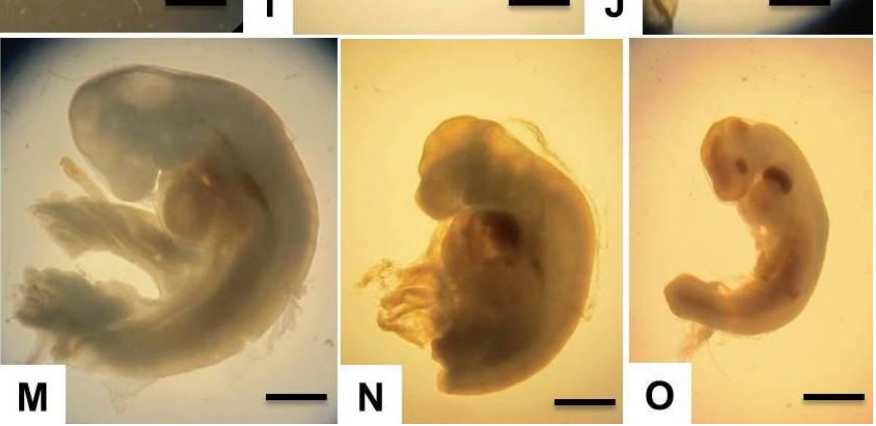

O saco vitelino situava-se na porção ventral dos embriões, próximo ao cordão umbilical, e se apresentou como uma estrutura pequena, contendo poucos vasos em sua membrana e com coloração amarelo-transparente, o que o diferenciava das outras estruturas (Figura 3B e C). Seu tamanho diminui conforme o crescimento do embrião e sua presença ainda eram vista na idade de 30 dias. 
O âmnio se apresentou intimamente ligado ao embrião com a idade de 20 dias, é a primeira das membranas fetais, considerando a ordem embrião/útero, e ainda nessa idade, quase não foi possível à observação de lpresença de líquido entre o embrião e membrana amniótica e este se apresentava avascularizado (Figura 3B). Na idade de 30 dias, quanto a sua forma, o âmnio possuía formato variável entre redondo e oval, onde não foi visível macroscopicamente a presença de vasos e quanto a sua coloração, esta membrana variava de transparente a esbranquiçada (Figura $3 C$ e D), a quantidade de liquido era grande quando comparada com a idade anterior.

A membrana coriônica apresentou-se como uma membrana pouco rugosa, onde, macroscopicamente são observadas suaves rugas. Em ambas as idades a membrana apresentou o inicio de processo de fusão, onde foi também observada uma pequena vascularização (Figura 3A, B e D).

A membrana alantóideana, do mesmo modo que o saco vitelino situava-se na porção ventral do embrião. Essa membrana, na idade de 20 dias, apresentou-se como uma bexiga com forma de lua crescente e em seu interior uma grande quantidade de liquido transparente. Em ambas idades, foi observada paredes transparentes onde é possível a visualização de uma intensa vascularização (Figura 3), e conforme a evolução da gestação a membrana alantóideana une-se ao córion, vista que na idade de 30 dias fica quase impossível à percepção das duas, formando a membrana córioalantóidea. 
Figura 3 - Fotomacrografia de embriões suínos de 20 e 30 dias de gestação.

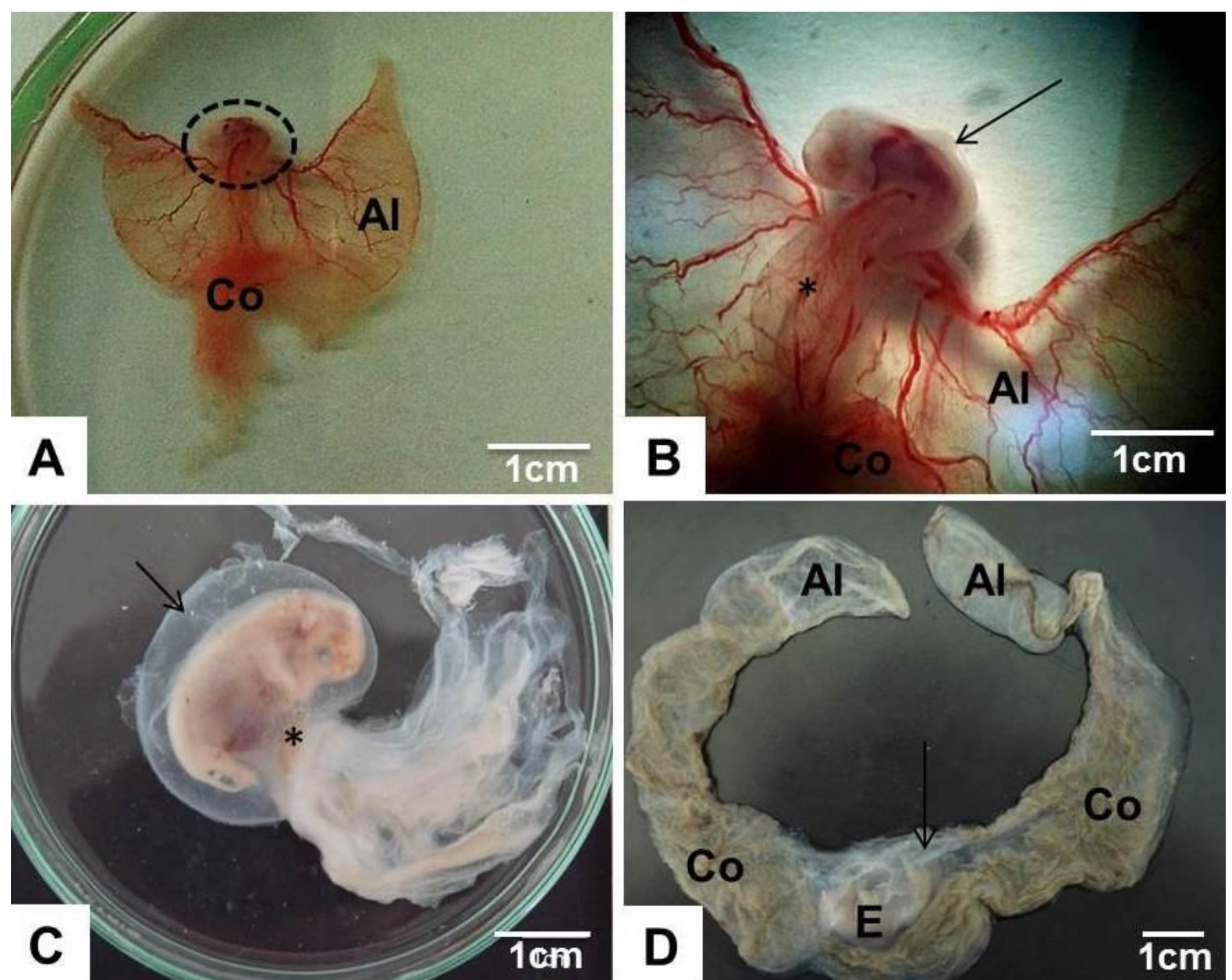

Legenda: A) Embrião de suínos com 20 dias de gestação. Embrião (Circulo pontilhado), Alantóide (Al) e Córion (Co). B) Embrião com 20 dias. Notar saco vitelino com coloração transparente (*), âmnio (seta), alantóide muito vascularizado (Al) e Córion (Co). C) e D) Embrião com 30 dias. Saco vitelino com coloração amarelada já em regressão $\left(^{*}\right)$, âmnio (seta), córion (Co) e alantóide (Al) já em justaposição, embrião (E).

\subsection{ANÁLISES HISTOLÓGICAS E IMUNOHISQUIMCA DAS MEMBRANAS EXTRAEMBRIONÁRIAS}

\subsubsection{Saco vitelino}

O saco vitelino dos suínos apresentou-se como uma estrutura trilaminar divida em 3 camadas: endoderma, mesênquima e mesotélio (Figura 4). O endoderma 
possuiu um epitélio simples cubico, onde apresentou núcleos circular intensamente corado pela hematoxilina (Figura 4A).

A camada que corresponde ao mesênquima, camada intermediaria, era delgada, apresentava uma grande quantidade de tecido conjuntivo e células arredondadas, com citoplasmas de coloração clara (Figura 4A, B e D). A região mesênquimal mostrou-se repleta de vasos com hemácias nucleadas (hemangioblastos) de origem fetal em seu interior, a essas estruturas dá-se o nome de ilhas eritroblásticas (Figura 4C e D).

O mesotélio apresentava-se como uma camada delgada e com células achatadas (Figura 4B). O epitélio vitelínico com o tecido conjuntivo formava dobras que se projetavam para a luz (Figura 4C).

Nas células endodérmicas do saco vitelino, de ambas as idades (20 e 30 dias), foi possível observar a intensa expressão de positividade para citoqueratina podendo assim a visualização de delimitação de uma célula junto à outra, já nas células do mesênquima e mesotélio poucas foram as marcações das células usando o anticorpo acima citado (Figura 4E e F).

Quando analisado a expressão de VEGF, foi observada uma maior intensidade no saco vitelino suíno de 20 dias, quando comparado com o material de 30 dias (Figura 4G e H). Uma vez que uma das funções do VEGF é gerar novos vasos sanguíneos durante o desenvolvimento do embrião, é de se esperar que em estágios mais precoces do desenvolvimento sua expressão seja mais intensa e primordial, pois sua ação está diretamente ligada ao desenvolvimento embrionário. 
Figura 4 - Fotomicrografia do saco vitelino de embriões suínos com 20 e 30 dias de gestação.

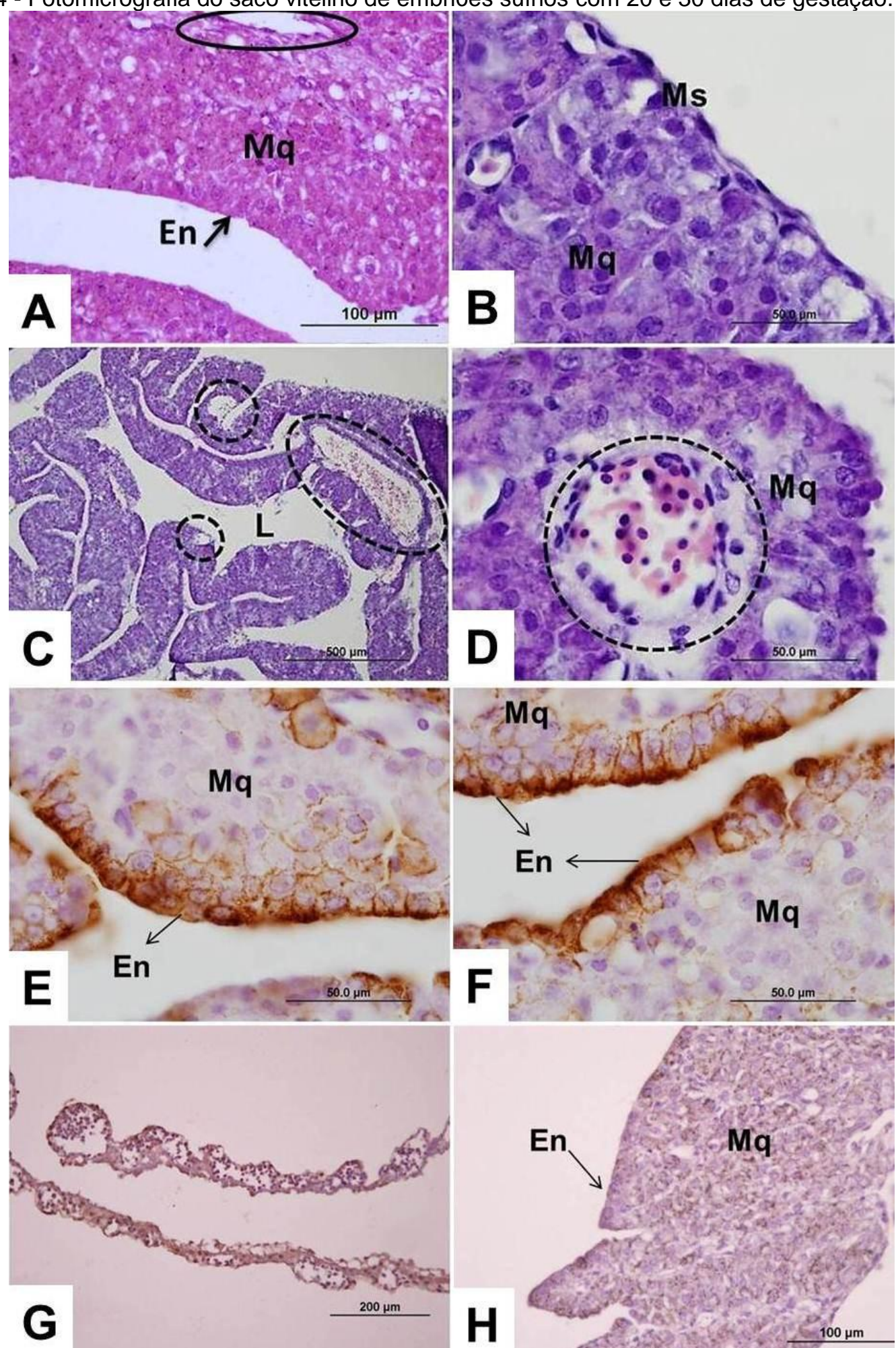

Legenda: $A / C / E / G$ membranas 20 dias e B/D/F/H membranas 30 dias. $A$ e B) Histologia do saco vitelino: composição das 3 camadas do saco vitelino, Endotélio (Em, seta), Mesênquima (Mq), Mesotélio (circulo). C e D) Histologia do saco vitelino: Ilhas vasculares nas porções do saco vitelino. Notar ainda em " $D$ " revestimento das ilhotas com células endoteliais e, interior, hemangioblastos (hemácias nucledas). Coloração, H/E. Imunohistoquímica do saco vitelino de embriões suínos de 20 dias (E/F) e 30 dias (G/H). E e F) Detecção de Citoqueratina; $G$ e H) Detecção de VEGF. Mesênquima (Mq) e endotélio (En). 


\subsubsection{Membrana Córioalantóide}

O córion é constituído por uma camada de células arredondadas, dispostas em formato linear de maneira regular e homogenia, aspecto semelhante a um epitélio simples cubico. Estas células são marcadas fortemente pelas colorações, ainda em relação ao aspecto da morfologia, as células apresentam aspectos cuboides, grandes e globosas (Figura 5A e C).

O alantóide é caracterizado por ser uma membrana com mesênquima amorfo e em seu interior uma quantidade pequena de células, e estas na idade de 20 dias apresentam um formato circular (Figura 5B) e com idade de 30 dias um formato alongado (Figura 5D).

Notamos que na idade de 20 dias há o inicio de fusão do córion com a membrana seguinte, o alantóide, e na idade de 30 dias essa fusão, denominada fusão córioalantóidea, já esta estabelecida (Figura 5C).

Em relação à marcação de Citoqueratina e de VEGF na membrana corioalantóide, observamos uma maior intensidade de VEGF na idade de 20 dias

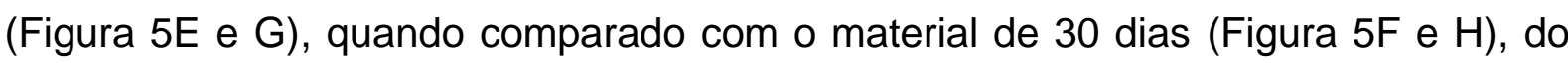
mesmo modo que ocorreu no saco vitelino. 
Figura 5 - Fotomicrografia da membrana córioalantóide de embriões suínos com 20 e 30 dias de gestação.

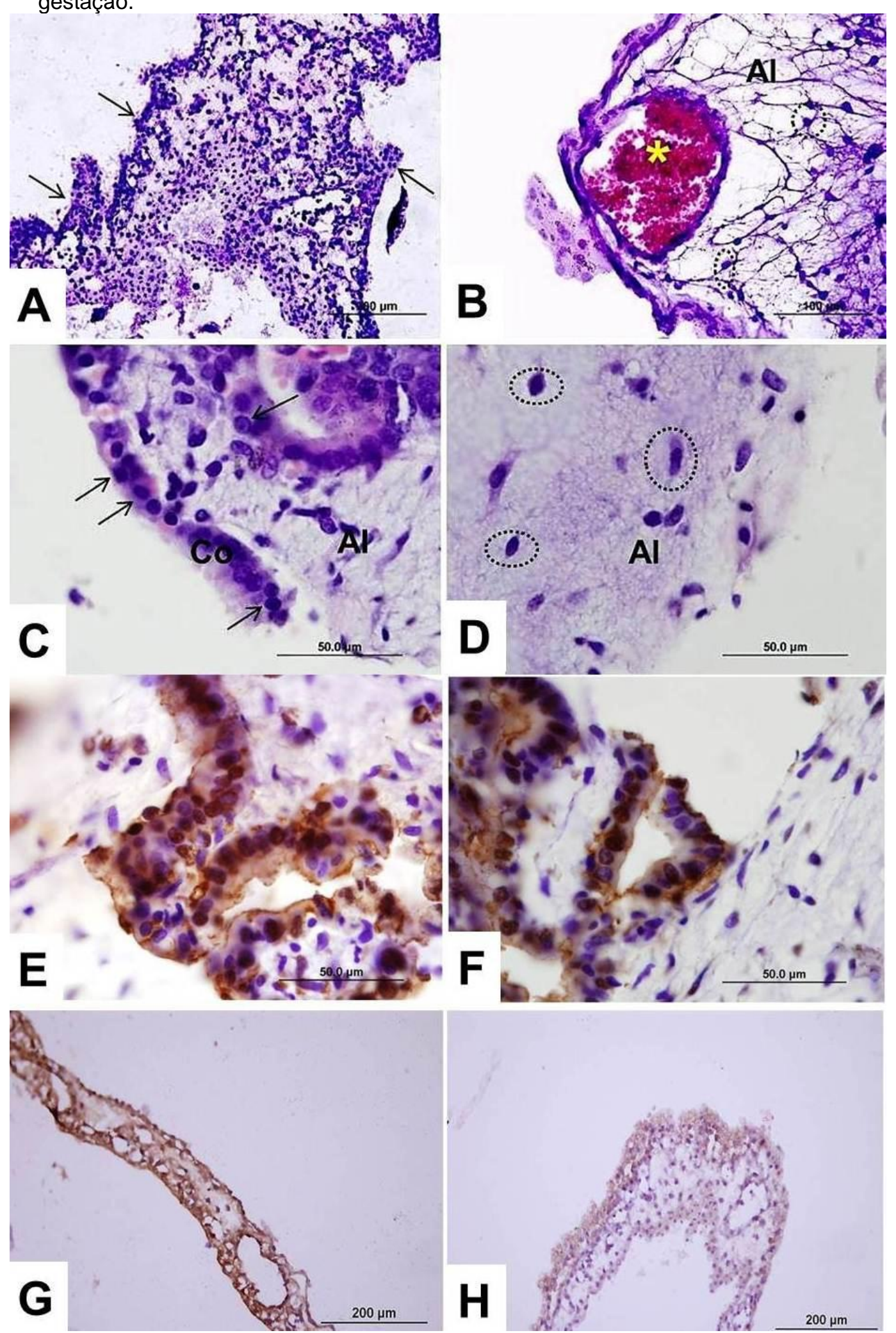

Legenda: $A / C / E / G$ membranas 20 dias e $B / D / F / H$ membranas 30 dias. Histologia das membranas córioalantíde: A) Corion, células globosas arredondadas (seta) do cório. B) Alantóide (Al) com células não alongadas (circulo pontilhado) e vasos (Asterisco amarelo). C) Córionalantóide. Células globosas no córion (setas finas), Córion (Co) e Alantóide (Al). D) Mesênquima do alantóide (Al) com células alongadas (Circulo pontilhado). Coloração H/E. Imunohistoquímica da membrana do corioalantóide de embriões suínos de 20 dias $(E / F)$ e 30 dias $(G / H)$. E e F) Detecção de Citoqueratina; $G$ e $H$ ) Detecção de VEGF. 


\subsubsection{Membrana Amniótica}

Não houveram diferenças histológicas entre a membrana amniótica da idade de 20 das e 30 dias (Figura 6).

A membrana amniótica é composta por duas camadas distintas. A primeira destas é constituída por uma fina e única camada de células ovaladas e achatadas, epitélio simples pavimentoso, onde o núcleo sempre é fortemente marcado (Figura $6 \mathrm{~A}$ e C). Assim como no alantóide, o mesênquima do âmnio é uma camada constituída de substancia amorfa onde é observada pouca quantidade de células. Este não se distribui de forma regular ao longo de toda membrana amniótica de forma que em algumas regiões nota-se diferença na sua espessura (Figura $6 \mathrm{~B}$ e D).

Em ambas as idades, somente nas células do epitélio simples cúbico amniótico foi possível à observação da expressão da reação positiva para a marcação dos anticorpos Citoqueratina e VEGF (Figura 6E, F, G e H). 
Figura 6 - Fotomicrografia da membrana Amniótica de embriões suínos com 20 e 30 dias de gestação.

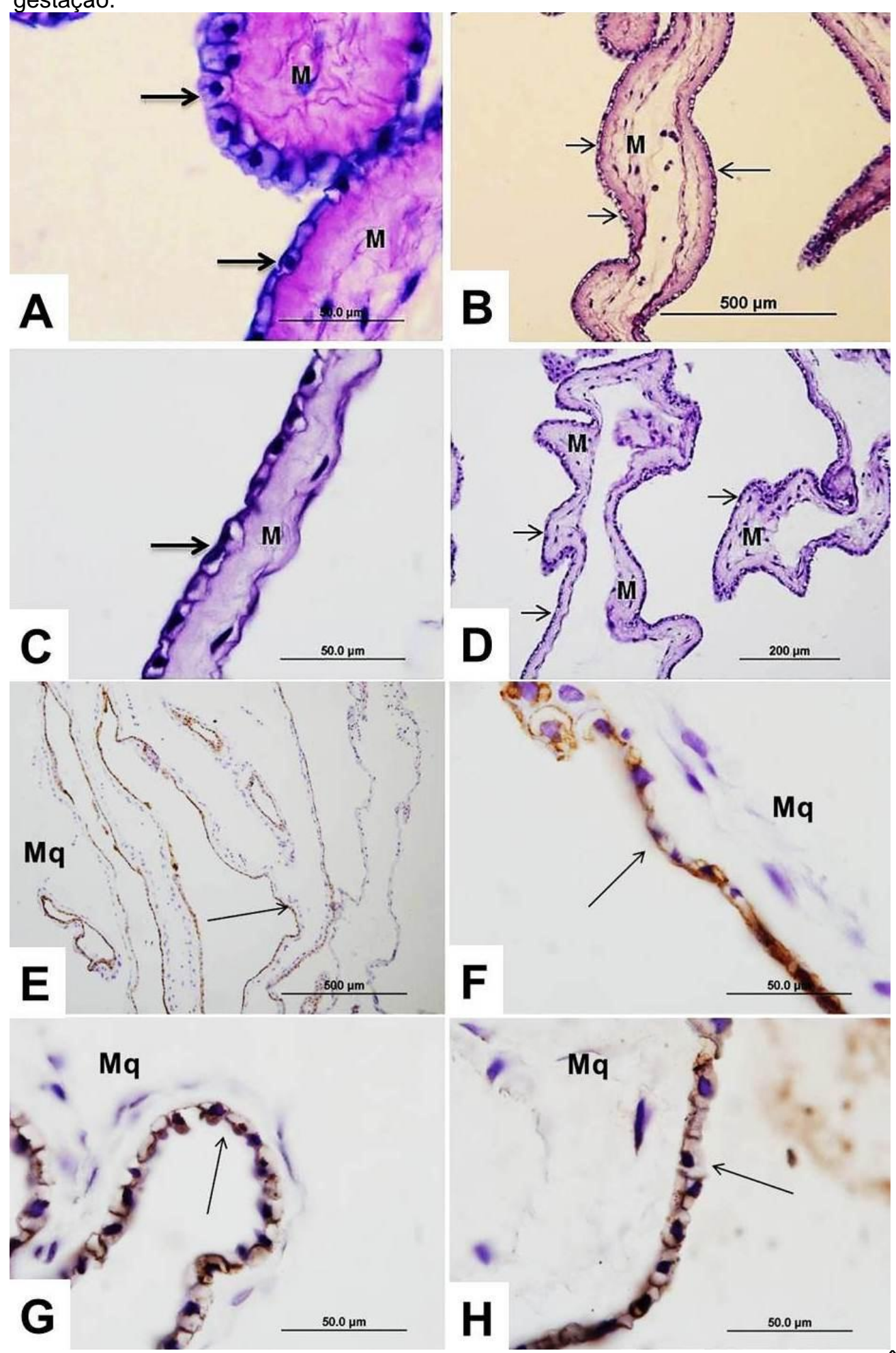

Legenda: $A / B / E / G$ membranas 20 dias e $C / D / F / H$ membranas 30 dias. Histologia: $A$ e B) Âmnio de embriões com 20 dias de gestação, células arredondadas e achatadas (seta) e mesênquima amorfo (M). C e D) Âmnio de embriões com 30 dias de gestação, células achatadas (seta) e mesênquima amorfo (M). Coloração H/E. Imunohistoquímica da membrana amniótica de embriões de suínos de 20 dias $(E / G)$ e 30 dias $(F / H)$. E e F) Detecção de Citoqueratina; $G$ e H) Detecção de VEGF. Mesênquima (Mq) e epitélio simples cubico (setas). 


\subsection{ANÁLISES DAS CÉLULAS-TRONCO OBTIDAS DO SACO VITELINO}

\subsubsection{Morfologia das células do saco vitelino de suíno}

Após o isolamento do saco vitelino, as células foram cultivadas conforme descrito em materiais e métodos.

Foi possível a observação de duas morfologias de células derivadas do saco vitelino: as células que inicialmente não aderiram à placa (aderência tardia) e apresentavam uma morfologia arredondada (Figuras 7A), e células que apresentavam logo de inicio aderência a placa e uma morfologia fusiformes semelhante a fibroblastos, justificando sua descrição clássica de aspecto fibroblastóide (Figura 7B, C e D). Estas apresentaram um crescimento rápido atingindo a confluência de $70 \%$ em aproximadamente 20 dias e puderam sofrer tripsinizações. As células não aderentes foram removidas da cultura durante as trocas do meio, que ocorreram a cada 3 dias.

Observamos que as células obtidas após explant celular apresentaram aderência ao plástico e, em aproximadamente 21 dias de cultura, já apresentavam pequenas colônias de células fibroblástóides que puderam ser tripsinizadas e subcultivadas. 
Figura 7- Fotomicrografia das células derivadas do saco vitelino de suínos com 20 e 30 dias de gestação.
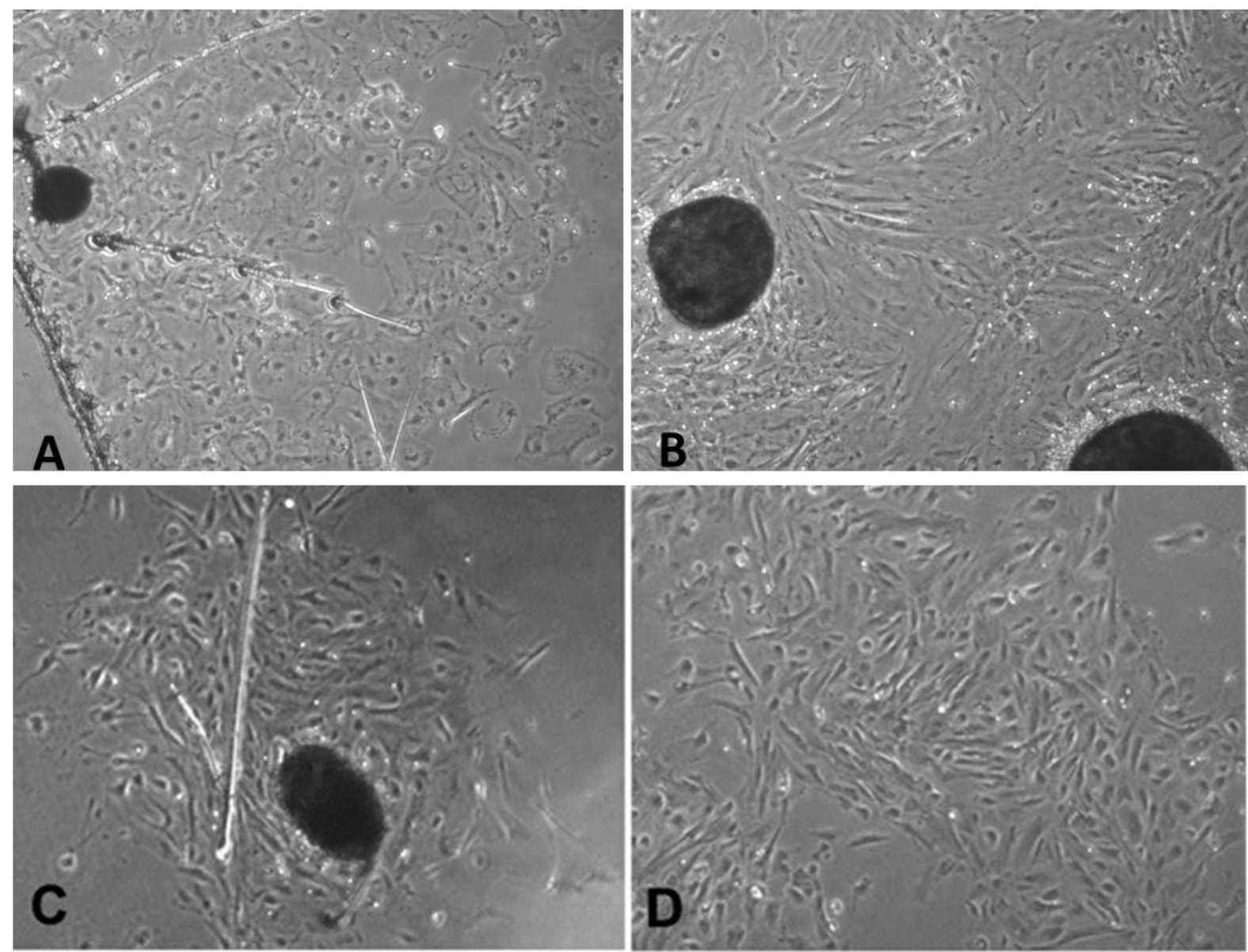

Legenda: Em A, explant de células de saco vitelino suíno de embrião de 20 dias, notar células de formato arredondado, com núcleo centralizado; em $\mathrm{B}$, explant de células de saco vitelino suíno de embrião de 30 dias, observar células alongadas, fusiformes.; $C$ e D) Cultura primária das células aderentes, antes da primeira tripsinização (Aumento 20x). Observar células dispersas aderidas ao redor do explant de tecido embrionário (em C) e células aderidas ao plástico com formato fibroblastóide em D. Observamos algumas diferenças na morfologia celular entre as células de 20 e 30 dias, diferenças estas sumarizadas na conclusão deste trabalho.

\subsubsection{Análise da curva de crescimento}

Observamos que estas células sofreram com a tripsinização, demorando mais tempo que comumente observados em outras linhagens para se recuperarem e voltarem a crescer em cultura. As células foram mantidas até a passagem P4, após esta elas começaram a sofrer morte celular com baixa taxa de sobrevivência e proliferação (Figura 8). 
Figura 8 - Curva de crescimento das células do saco vitelino suíno (SVS) $1.10^{5}$ celulass $/ \mathrm{mL} x$ tempo em dias (24hs)

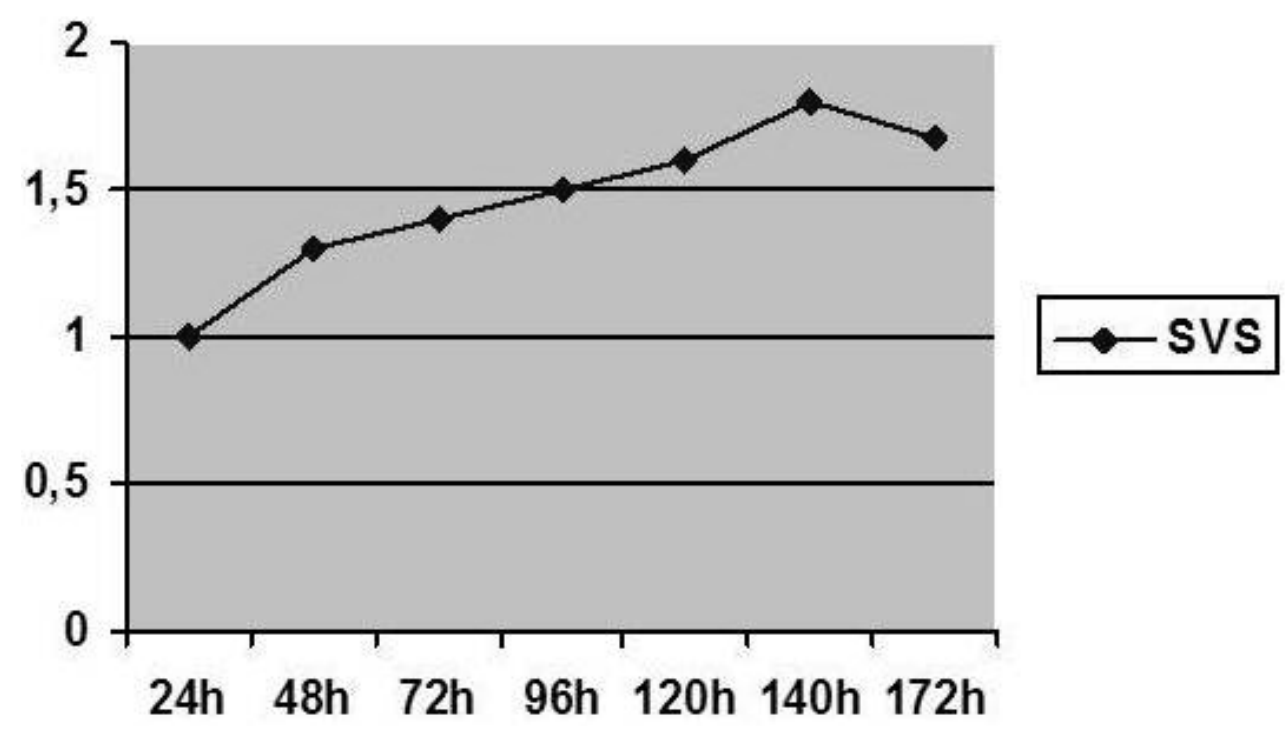

\subsubsection{Imunofenotipagem por citometria de fluxo}

Os resultados por citometria de fluxo demonstraram que a células apresentam características imunofenotípicas semelhantes às células-tronco mesenquimais, expressando positividade para os marcadores CD105 (marcador endotelial atuante no desenvolvimento embrionário), CD45, Nanog e OCT3/4 (Figura 9 e 10). 
Figura 9 - Citometria de Fluxo. Gráfico mostrando a porcentagem células de saco vitelino com 30 dias de gestação positivas para os marcadores CD105, CD45, Nanog e Oct3/4.

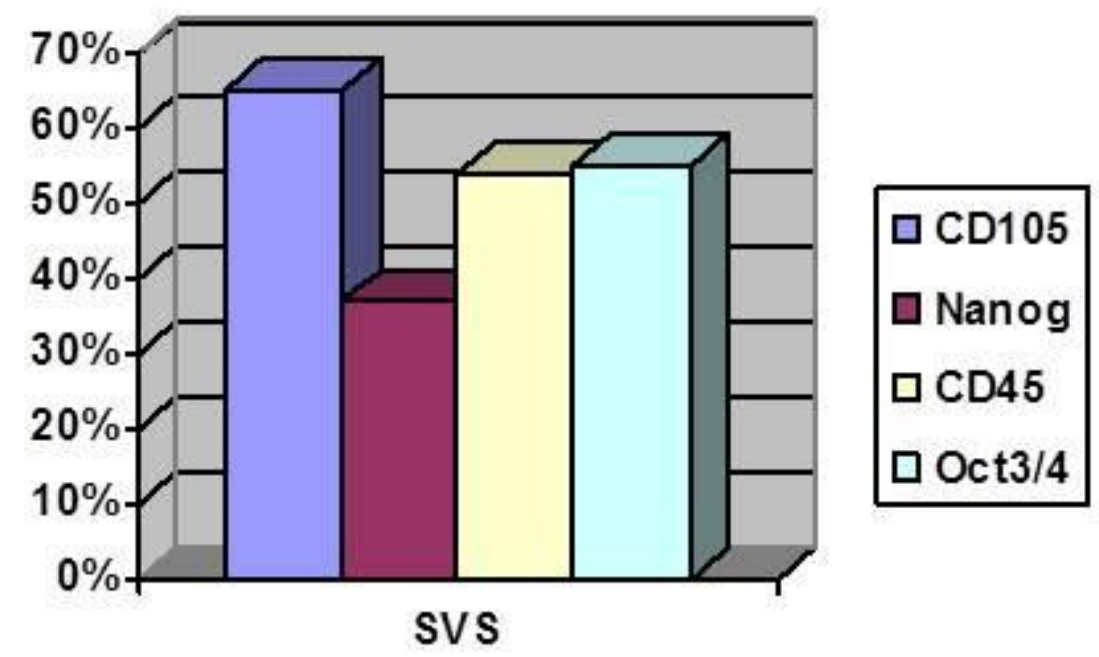

Figura 10 - Citometria de fluxo complementar do gráfico demonstrando células positivas para os marcadores CD105, Nanog, CD45 e OCT4/3.
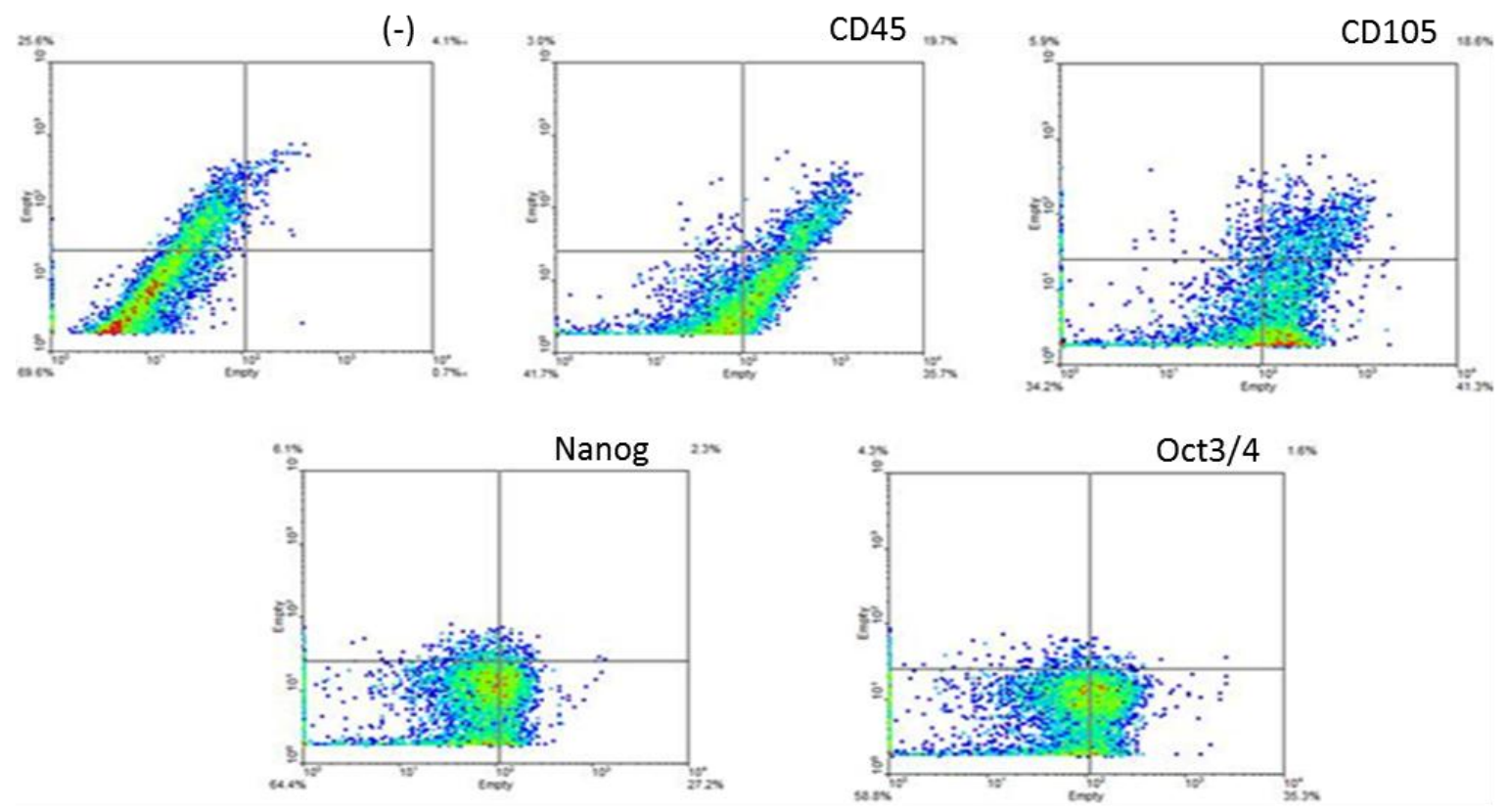

\subsubsection{Imunocitoquimica}

Os resultados da imunocitoquimica demonstraram que a células possuem algumas características imunofenotípicas de células-tronco mesenquimais, como expressão para marcadores de CTM (CD105, CD90, Vimentina e Citoqueratina) e 
células-tronco hematopoéticas, expressão para marcadores de CTH (CD 117).

Estas células apresentaram também, positividade para determinados marcadores associados a pluripotência (Stro-1, OCT-4), proliferação celular (PCNA), crescimento endotelial vascular (VEGF, beta tubulina). 
Figura 11- Imunocitoquímica das CTMs do saco vitelino de suínos com 30 dias de gestação. Positividade para os marcadores CD90, CD105, CD117, Vimentina, Stro-1, OCT-4.

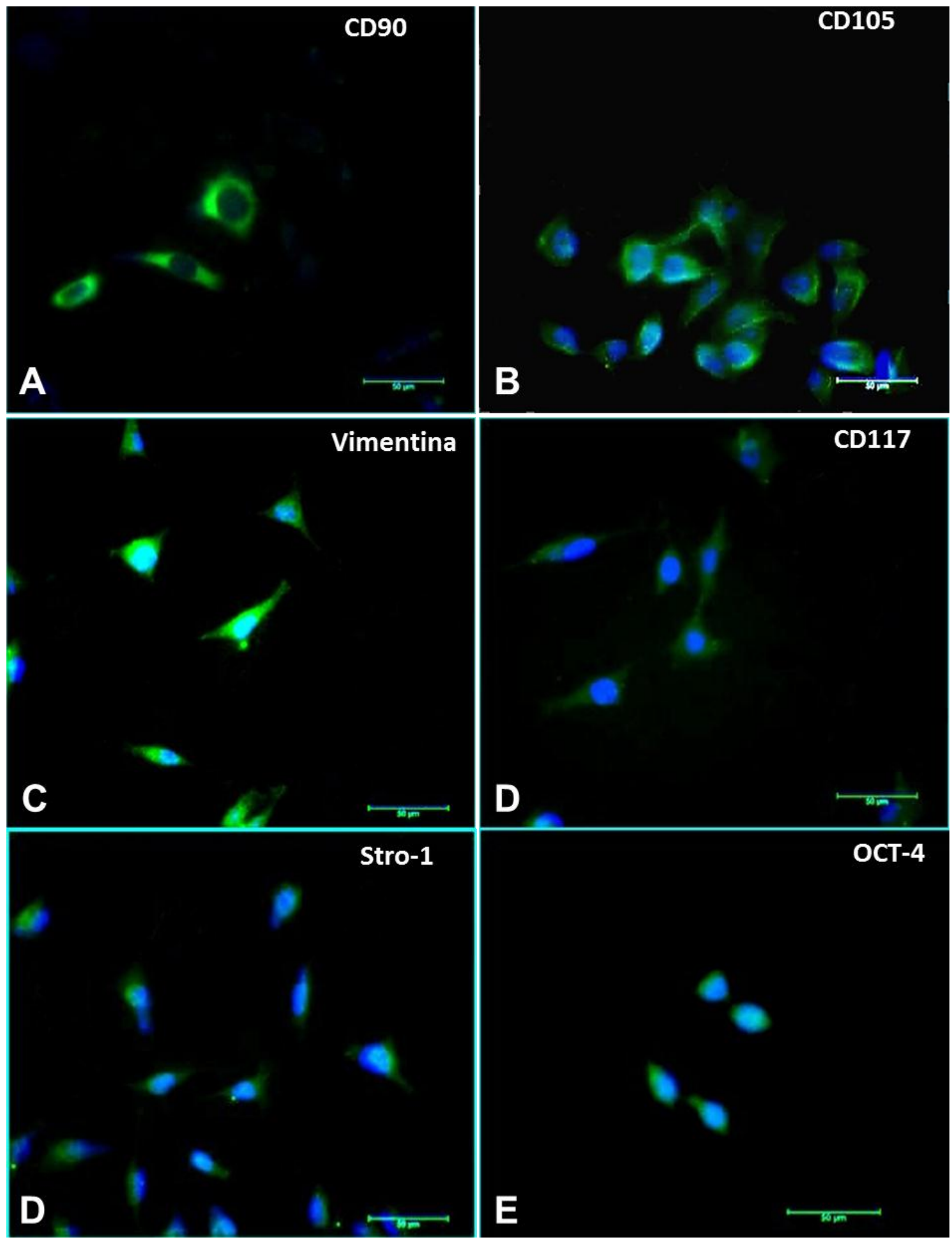


Figura 12- Imunocitoquímica das CTMs do saco vitelino de suínos com 30 dias de gestação. Positividade para os marcadores VEGF, Beta tubulina, Ck, PCNA.

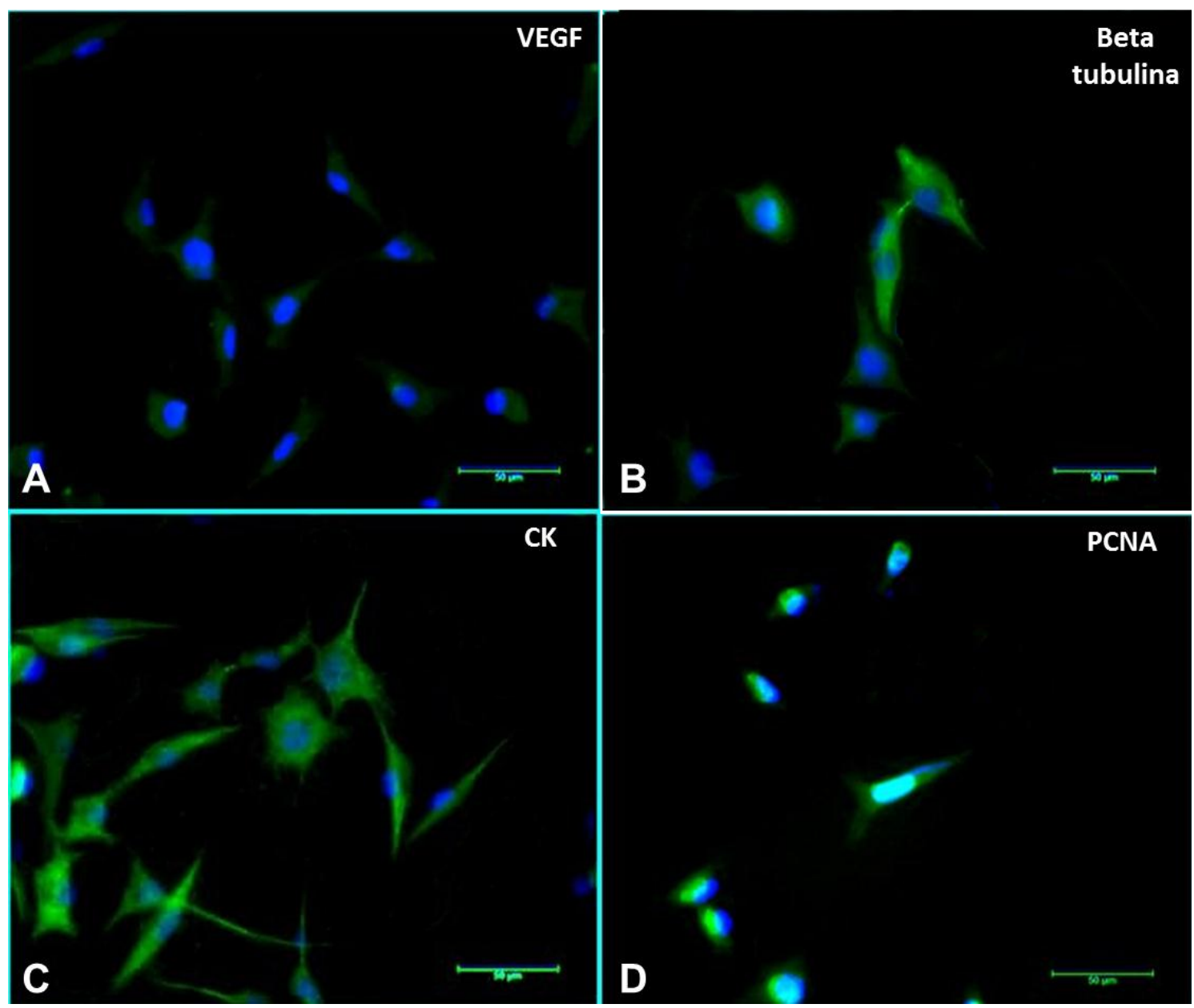

Legenda: Imunopositividade. A) marcador VEGF; B) marcador Beta tubulina; C) marcador Citoqueratina; D) marcador PCNA 


\section{DISCUSSÃO}

O saco vitelino dos embriões de suínos começa sua regressão a partir do $18^{\circ}$ dia de gestação, quando se inicia a formação da placenta definitiva (TALBOT et al., 2007). Isso foi confirmado no presente estudos, pois, comparando o saco vitelino dos embriões com idade gestacional de 20 e 30 dias nota-se uma drástica diminuição dessa estrutura, mostrando assim uma constante regressão.

O saco vitelino do suíno está localizado na porção ventral do embrião, próximo ao cordão umbilical, essa localização também é descrita em bovinos, onde permanece conectado ao intestino posterior do embrião, mediante sua porção central (ASSIS NETO et al., 2012).

Microscópicamente o saco vitelino do suíno é composto por três camadas: endoderma, mesotélio e mesênquima; do mesmo modo que é descrito na espécie bovina por Assis Neto (2005) e Mançanares (2007).

Zago e Covas (2006) descrevem que em humanos, aproximadamente duas a três semanas após a fertilização e implantação do ovo no endométrio, surge no mesênquima lateral agrupamento de células, denominados "ilhotas sanguíneas". As células externas das ilhotas vasculares são diferenciadas em células endoteliais, enquanto as internas em sangue primitivo ( $\mathrm{CHO}$ et al., 2006). Para Palis e Yoder (2001) o saco vitelino também é o primeiro local de produção de células sanguíneas no rato e no homem, onde células eritrocíticas primitivas originam no saco vitelino e completam sua maturação incluindo enucleação, na circulação sanguínea. No presente estudo os achados estão em acordo com as descrições acima, pois quando analisado, foi encontrado no mesênquima do saco vitelino uma grande quantidade de ilhas sanguíneas e em seu interior hemácias nucleadas (hemangioblastos).

Aos 20 dias de gestação nota-se uma enorme vascularização no alantóide e o inicio da fusão desta membrana com o córion. Aos 30 dias há fusão completa dessas duas membranas, dando origem a membrana córioalantóidea, corroborando com nossos resultados está Friess et al., (1980), onde cita que em suínos, a partir do $14^{\circ}$ dia o alantóide está em fase de crescimento e atinge o dobro do tamanho do embrião aos 18 dias de gestação, ao dia 19 o alantóide funde-se com o córion para formar a membrana corioalantóide, e aos 30 dias essa estrutura esta completamente 
vascularizada com vasos de origem alantóica.

No alantóide foi possível a observação de vários vasos ao seu redor; conforme a evolução da gestação a membrana alantóideana une-se ao córion, vista que na idade de 30 dias fica quase impossível à percepção das duas, esses resultados entram em acordo com Kaufmann e Burton (1994), que relatam que o córion é responsável pela troca materno-fetal e apresenta uma circulação funcional. Entretanto, o córion, é um tecido intrinsecamente avascular, sendo vascularizado exclusivamente por vasos do alantóide.

No que diz respeito a microscopia, o alantoide do suíno se apresenta como uma camada simples de células pavimentosas, e o mesênquima extremamente vascularizado, esses achados são semelhantes aos achados de Assis Neto (2005), quando relata em seus estudos com bovinos essa característica.

No embrião suíno com idade gestacional de 20 dias a membrana coriônica não é lisa, diferentes da membrana coriônica de bovinos, onde esta se apresenta relativamente delgado e frágil de coloração esbranquiçada e lisa (BARONE, 1986).

A membrana amniótica do suíno mostrou-se como uma membrana transparente, contendo em seu interior um líquido transparente (liquido amniótico), este relato está de acordo com Schwarze (1970), Barone (1986) e Noden e De Lahunta (1990) que cita essas características em ruminantes.

Segundo Assis Neto (2005), a membrana amniótica nos bovinos, é constituído de epitélio pavimentoso, continuo e possuindo células organizadas em linha, e este se apoia em uma camada de tecido conjuntivo, que constitui o mesênquima, esses relatos entram de acordo com o estudo aqui realizado, onde também foi possível, através de miscroscopia de luz, a observação e diferenciação dessas duas camadas (epitélio simples pavimentoso e mesênquima), que por sua vez corroboram com Steven (1982), onde relata que essa morfologia uniforme entre as células do âmnio não difere de outros mamíferos.

A origem endodérmica do saco vitelino, amnio e epitélio simples cubico do alantóide foram demonstradas pela marcação da imunohistoquimica de citoqueratina. Todos os tipos de células epiteliais com origem endodérmica e ectodérmica apresentam marcação positivas para citoqueratina (BAKER et al., 1993; NORDSTOGA; ALEKSANDERSEN, 1998).

Já as células do mesênquima e do mesotélio do saco vitelino apresentaram pouca marcação de citoqueratina, devido à transição epitelial-mesenquimal 
envolvendo a reorganização do citoesqueleto (BAKER et al., 1993).

As células epiteliais possuem filamento intermediário de citoqueratina (ROJAS et al., 1998) durante a transformação em mesenquimal. Estes filamentos são substituídos por filamentos de vimentina que são características de células mesenquimais (STEINER; ROOP, 1988), onde ocorre uma degradação progressiva da citoqueratina ao longo do processo, isto implica na localização da citoqueratina em células mesenquimais sendo um marcador de origem recente epitelial.

Quando analisada a expressão de VEGF no saco vitelino suíno no período gestacional de 20 e 30 dias, observamos uma expressão mais intensa de VEGF no saco vitelino suíno de 20 dias, quando comparado com o material de 30 dias. Uma vez que uma das funções do VEGF é gerar novos vasos sanguíneos durante o desenvolvimento do embrião, é de se esperar que em estágios mais precoces do desenvolvimento sua expressão seja mais intensa e primordial, pois sua ação está diretamente ligada ao desenvolvimento embrionário (BERTASSOLI et al., 2012; SANTOS et al., 2012; TOMASI JR et al., 2012)

Em relação à morfologia, as CTMs oriundas do saco vitelino de embriões suínos, estas possuíam um formato fusiformes semelhante a fibroblastos, justificando sua descrição clássica de aspecto fibroblastóide, núcleo grande e projeções em suas extremidades, achados que entram em concordância com Ringe et al., (2002), Tagami et al., (2003), Bosch, Pratt, Stice (2006) onde os autores relatam em seu trabalho que as CTMs possuem formato fibroblastóide alongado.

Deans e Moseley (2000) citam em seu estudo que as CTMs quando cultivadas em baixa densidade a adesão e formação de colônias é rápida, resultados que corroboram com nossos resultados obtidos com CTMs do saco vitelino (confluência 80\% em torno de 21 dias).

Segundo Fehrer e Lepperdinger (2005) as CTMs sofrem com as passagens e tripsnizações, ocorrendo uma proliferação lenta e até morte celular, corroborando com esse estudo está o nosso, onde a partir da passagem 3 há um decréscimo no crescimento celular e após a passagem 4 morte celular.

As células-tronco oriundas do saco vitelino demonstraram positividade para marcadores como CD105, CD90, Stro-1, OCT-4 e PCNA, aderência ao plástico, morfologia fibroblastóide e quando cultivadas em baixa concentração, apresentaram uma alta proliferação, sendo assim, estas células oriundas do saco vitelino podem ser considerada CTM, pois, segundo Kolf et al., (2007) e Lacono et al., (2010) estas 
características são propostas pelo International Society for Cellular Therapy para classificação de células-tronco mesenquimais.

A expressão de CD105 (endoglina) é preferencialmente expressão em vasos em proliferação durante a angiogênese, ou seja, expressos em células que darão origem a outras células (células-tronco) (VASCONCELOS et al., 2011), nas células do saco vitelino essa expressão foi mostrada em imunocitoquímica, logo, essas células oriundas do saco vitelino fazem parte do processo de vasculogenese inicial do embrião.

Células do saco vitelino foram imunopositivas para o marcador CD117, corroborando com Meirelles, Chagastelles, Nardi (2006), que cita em seu trabalho que esse marcador é usado para marcar células-tronco indiferenciadas de várias estruturas do corpo, como por exemplo, a medula óssea.

Segundo Sabatini et al. (2005) e Souza et al. (2010) existem vários marcadores de células-tronco mesenquimais, porém, os marcadores que têm sido utilizados para melhor seleção de células-tronco mesênquimais são Stro-1, CD271, CD73 e CD 105, logo, quando as submetidas a imunocitoquímica, as células do saco vitelino expressaram 2 desses marcadores, indicando serem células-tronco mesenquimais.

Outro anticorpo utilizado para caracterizar com a imunomarcação as célulastronco mesênquimais é o anticorpo anti-vimentina (BITTENCOURT et al., 2006), o que nos leva a pensar mais uma vez que, estas células aqui estudadas possuem grandes características de células-tronco mesênquimais, pois expressaram também esse marcador quando utilizada a técnica de imunocitoquímica.

Porém, estas células, provenientes do saco vitelino, também apresentaram positividade para marcadores de células hematopoiéticas (CD45 e CD117), corroborando com outros estudos que citam que o saco vitelino é responsável pela produção de células sanguíneas e endoteliais que inicia o a construção do plexo vascular do embrião (BARON, 2003; CHOI, 2002; GALDOS et al., 2010; MCGRATH; PALIS, 2005; PALIS; YOUDER, 2001; SANTOS et al., 2012; WOLF et al., 2003). 


\section{CONCUSÕES}

Do estudo realizado sobre a histologia e comparação das membranas extraembrionárias de suínos com 20 e 30 dias de gestação podemos concluir que:

O processo de fusão cório/alantóide está presente na idade de 20 e 30 dias de gestação.

O alantóide é a membrana responsável pela vascularização do córion.

O saco vitelino é a membrana responsável pela produção das primeiras células sanguínea do concepto, persistindo ate o ultimo período estudado nesse trabalho (30 dias).

Não houve grandes alterações histológicas nas membranas extraembrionárias nas idades comparadas, exceto no alantóide, onde as células do mesênquima na idade de 20 dias de gestação se mostraram como células pequenas e arredondadas, e na idade de 30 dias, se mostraram como células grandes e com formato alongado.

Das culturas celulares obtidas das células do saco vitelino de embriões de suínos concluímos que:

O meio de cultura Alpha Mem suplementado com soro fetal bovino mostrou-se ideal para o cultivo destas células.

Estas células mostraram aderência ao plástico após 7 dias de explant celular.

As células do saco vitelino obtidas apresentam positividade para os marcadores CD105, CD45, Nanog e OCT3/4, resultados comprovados por citometria de fluxo.

As células do saco vitelino apresentaram positividade para os marcadores CD90, CD105, Vimentina, CD117, Stro-1, Oct4, VEGF, Beta Tubulina, Citoqueratina e PCNA, resultados comprovados por ensaios de imunocitoquímica.

Estas células apresentaram positivadades para marcadores hematopoiéticos como o CD45.

Por estes resultados, podemos comprovar que as células do saco vitelino de suínos possuem características semelhantes às células-tronco mesênquimais e embrionárias, sendo considerada uma ferramenta importante para futuros estudos experimentais de terapia celular na medicina veterinária regenerativa. 


\section{REFERÊNCIAS}

ALMEIDA JR, H. L. Citoqueratinas. Anais Brasileiros de Dermatologia, v. 79, n. 2, p. 135-145, 2004.

ALVES, P. M. M.; CARRONDO, M. J. T.; CRUZ, P. E. Introdução à Tecnologia de cultivo e células animais. In: MORAES, A. M.; AUGUSTO, E. F. P.; CASTILHO, L. R. Tecnologia do Cultivo de Células Animais: de Biofármacos a Terapia Celular.

São Paulo: Roca, 2007. p. 2-14.

ASSIS NETO, A. C. Avaliação morfológica da placentação em bovinos de gestações normais e gestações manipuladas em laboratórios. 2004. 220 f. Exame qualificação - Faculdade de Medicina Veterinária e Zootecnia, Universidade de São Paulo, São Paulo, 2005.

ASSiS NeTO, A. C.; OliveIRA, F. D.; CONSTANTINO, M. V. P.; MIGLINO, M. A. Morphology and Involution of the Yolk Sac during Early Gestation Bovine (Bos indicus). Acta Scientiae Veterinariae, v. 40, n. 4, p. 1-9, 2012.

BAKER, D. C.; SCHMIDT, S. P.; LANGHEINRICH, K. A.; CANNON, L.; SMART, R. A. Bovine myocardial epithelial inclusions. Veterinary Pathology, v. 30, p. 82-88, 1993.

BARRY, F. P.; BOYNTON, R. E.; HAYNESWORTH, S.; MURPHY, J. M.; ZAIA, J. The monoclonal antibody $\mathrm{SH}-2$, raised against human mesenchymal stem cells, recognizes an epitope on endoglin (CD105). Biochemical and Biophysical

Research Communication, v. 265, n. 1, p. 134-139, 1999.

BARRY, F. P.; MURPHY, J. M. Mesenchymal stem cells: clinical application and biological characterization. The International Journal of Biochemistry e Cell Biology, v. 36, p. 568-584, 2004.

BARON, M. H. Embryonic origins of mammalian hematopoiesis. Experimental hematology, v. 31, n. 12, p. $1160-1169,2003$.

BARONE, R. Anatomie comparée dês mammiféres domestiques:

Splanchnologie. Paris: Vigot Frères, 1986. 605 p.

BAVIK, C. ; WARD, S. J. ; CHAMBOM, P. Developmental abnormalities in cultured mouse embryos deprived of retinoic by inhibition of yolk-sac retinol binding protein synthesis. Proceedings of the National Academy of Sciences of the United

States of America, v. 93, p. 3110-3114, 1996. 
BEHMER, O. A. Manual de técnicas para histologia e patologia. São Paulo: Edart. 1976, $241 \mathrm{p}$.

BERTASSOLI, B. M.; OLIVEIRA, F. D.; SANTOS, A. C. MIGLINO, M. A.; ASSIS NETO, A. C. Expressões Gênicas nas Membranas Extraembrionárias e suas Conexões na Espécie de Murina e Bovina. Sabios: Revista Saúde e Biologia, v. 7, n. 2. P. 90-101, 2012.

BIANCO, P.; ROBEY, P. G.; SIMMONS, P. J. Mesenchymal stem cells: revisiting history, concepts, and assays. Cell Stem Cell, v. 2, p. 313-319, 2008.

BIANCO, P.; KUZNETSOV, S. A.; RIMUNICCI, M.; ROBEY, P. G. Postnatal Skeletal Stem Cells. Methods in Enzimology, v. 419, p. 117-148, 2006.

BITTENCOURT, R. A. C.; PEREIRA, H. R.; FELISBINO, S. L.; MURADOR, P.; OLIVEIRA, A. P. E.; DEFFUNE, E. Isolamento de células-tronco mesênquimais da medula óssea. Acta Ortopédica Brasileira, v. 14, n. 1, p. 22-24, 2006.

BOSCH, P.; PRATT, S. L.; STICE, S. L. Isolation, characterization, gene modification and nuclear reprogramming of porcine mesenchymal stem cells. Biology of Reproduction, v. 74, p. 46-57, 2006.

BREVINI, T. A. L.; TOSSETI, V.; CRESTAN, M.; ANTONINI, S.; GANDOLFI F. Derivation and characterization of pluripotent cell lines from pig embryos of different origins. Theriogenology, v. 67, p. 54-63, 2007.

BRYDEN, M. M.; EVANS, H. E.; BINNS, W. Embriology of the sheep: extraembryonic membranes and development of body form. Journal of morphology, v. 138, n. 2, p. 169-185, 1972.

BYDLOWSKI, S, P.; DEBES, A, A.; MASELLI, L, M, F.; JANZ, F, L. Características biológicas das células-tronco mesenquimais. Revista Brasileira de Hematologia e Hemoterapia, v. 31, p. 25- 35, 2009.

CAPLAN, A. I. Mesenchymal stem cells: cell-based reconstructive therapy in orthopaedics. Tissue engineering, v. 11, p.1198, 2005.

CHEN, L. R.; SHIUE, Y. L.; BERTOLINI, L.; MEDRANO, J. F.; BONDURANT, R. H.; ANDERSON, G. B. Establishment of pluripotent cell lines from porcine preimplantation embryos. Theriogenology, v. 52, n. 2, p. 195-212, 1999. 
CHO, F. N.; CHEN, S.; TAI, M. H.; YAN, T. L. The quality and size of yolk sac in early pregnancy loss. Australian and New Zealand Journal of Obstrtics and Gynaecology, v. 46, p. 413-418, 2006.

$\mathrm{CHOI}, \mathrm{K}$. The hemangioblast: a common progenitor of hematopoietic and endothelial cells. Journal of Hematotherapy \& Stem Cell Research, v. 11, n. 1, p. 92-101, 2002.

DEANS, R. J.; MOSELEY, A. B. mesenchymal stem cells: biology and potential clinical uses. Experimental Hematology, v. 28, n. 8, p. 875-884, 2000.

DEREN, J. J.; PADYKULA, H. A.; WILSON, T. H. Development os structure and function in the mammalian yolk sac. Developmental Biology, v. 13, p. 311-348, 1966.

DOETSHMAN, T.; WILLIAMS, P.; MAEDA, N. Establishment of hamster blastocystderived embryonic stem (ES) cells. Developmental Biology, v.127, p.224-227, 1988.

DOMINICI, M.; LE BLANC, K.; MUELLER, I.; SLAPER-CORTENBACH, I.; MARINI, F.; KRAUSE, D.; DEANS, R.; KEATING, A.; PROCKOP, D.; HORWITZ, E. Minimal criteria for defining multipotent mesenchymal stromal cells: The International Society for Cellular Therapy position statement, Cytotherapy, v. 8, p. 315-317, 2006.

EVANS, M. J.; KAUFMAN, M. H. Establishment in culture of pluripotential cells from mouse embryos. Nature, v. 292, p. 154-156, 1981.

FEHRER, C.; LEPPERDINGER, G. Mesenchymal stem cell aging. Experimental Gerontology, v. 40, n. 12, p. 926-930, 2005.

FILSHIE, R.J.; ZANNETTINO, A. C.; MAKRYNIKOLA, V.; GRONTHOS, S.; HENNIKER, A. J.; BENDALL, L. J.; GOTTLIEB, D. J.; SIMMONS, P. J.; BRADSTOCK, K. F. MUC18, a member of the immunoglobulin superfamily, is expressed on bone marrow fibroblasts and a subset of hematological malignancies. Leukemia, v. 12, p. 414-421, 1998.

FRIESS, A. E.; SINOWATZ, F.; SKOLEK-WINNISH, R; TRÄUTNER, W. The placentaof the pig. I. Finestructural changes of the placental barrier during pregnancy. Anatomy and Embryology, v. 158, n. 2, p. 179-191, 1980. 
GALDOS, A. C. R.; REZENDE, L. C.; PESSOLATO, A. G. T.; MIGLINO, M. A. A relação biológica entre saco vitelino e o embrião. Enciclopédia biosfera, v. 6, n. 11, p. 1-13, 2010.

GRAVES, K. H.; MOREADITH, R. W. Derivation and characterization of putative pluripotential ES cell lines from preimplantation rabbit embryos. Molecular

Reproduction and Development, v. 36, p. 424-433,1993.

GRONTHOS, S.; ZANNETTINO, A. C.; GRAVES, S. E.; OHTA, S.; HAY, S. J.; SIMMONS, P. J. Differential cell surface expression of the STRO-1 and alkaline phosphatase antigens on discrete developmental stages in primary cultures of human bone cells. Journal of Bone Mineral Research, v. 14, p. 47-56, 1999.

HAAR, J. L.; ACKERMAN, G. A. Phase and electron microscopic study of vasculogenesis and erythropoieses in the yolk sac of the mouse. Anatomic Record, v. 170, p. $199-224,1971$.

HORWITZ, E. M.; PROCKOP, D. J.; FITZPATRICK, L. A.; KOO, W. W.; GORDON, P. L.; NELL, M.; SUSSMAN, M.; ORCHARD, P.; MARX, J. P.; PYERITZ, R. E.; BRENNER, M. K. Transplantability and therapeutic effects of bone marrow derived mesenchymal cells in children with osteogenesis imperfecta. Nature Medicine, v.5, p. 309-315, 1999.

IANNACCONE, P. M.; TABORN, G. U.; GARTON, R .L.; CAPLICE, M. D.; BRENIN, $D$. R. Pluripotent embryonic stem cells from the rat are capable of producing chimeras. Developmental Biology, v. 163, p.288-292, 1994.

INTERNATIONAL COMMITTEE ON VETERINARY GROSS ANATOMICAL NOMENCLATURE. Nomina anatomica veterinaria. 4. ed. New York: Word Association on the Veterinary Anatomist, 2005. $166 \mathrm{p}$.

INTERNATIONAL COMMITTEE ON VETERINARY GROSS EMBRIOLOGYCAL. Nomina Embriological. 2. ed. Zurich: Word Association on the Veterinary Anatomist, 1994. 105 p.

INTERNATIONAL COMMITTEE ON VETERINARY GROSS HISTOLOGICAL NOMECLATURA. Nomina histological. 2. ed. Itacha: Word Association on the Veterinary Anatomist, 1994. 105 p. 
NORDSTOGA, K.; ALEKSANDERSEN, M.Epithelial inclusions in the bovine myocardium. Veterinary Pathology, v. 24, p. 525-526, 1998.

JAISWAL, N.; HAYNESWORTH, S. E.; CAPLAN, A. L.; BRUDER, S. P. Osteogenic differentiation of purified, culture-expanded human mesenchymal stem cells in vitro. Journal of Cellular Biochemistry, v. 64, p. 295-312, 1997.

JANZEN, R. G.; MABLY, E. R.; TAMAOKI, T. Synthesis of alpha-fetoprotein by the pre-implantation and post-implantation bovine embryo. Journal of reproduction and fertility, v. 65, p. 105-110, 1982.

JONES, E. A.; ENGLISH, A.; KINSEY, S. E.; STRASZYNSKI, L.; EMERY, P.; PONCHEL, F.; MCGONAGLE, D. Optimization of a flow cytometry-based protocol for detection and phenotypic characterization of multipotent mesenchymal stromal cells from human bone marrow. Cytometry part B Clinical Cytometry, v. 70, n. 6, p. 391399, 2006.

KAUFFMANN, P.; BURTON, G. Anatomy and genesis of the placenta. In: KNOBIL, E.; NEILL, J. D. The physiology of reproduction. New York: Raven Press, 1994. p. 441-484.

KIM, S.; KIM, J. H.; LEE, E.; JEONG, Y. W.; HOSSEIN, M. S.; PARK, S. M.; PARK, S. W.; LEE, J. Y.; JEONG, Y. I.; KIM, H. S.; KIM, Y. W.; HYUN, S. H.; HWANG, W. S.

Establishment and characterization of embryonic stem-like cells from porcine somatic cell nuclear transfer blastocysts. Zygote, v.18, n. 2, p. 93-10, 2010.

KOBAYASHI, N.; NIYAZAKI, M.; FUKAYA, K.; INOVE, Y.; SAKAGUCHI, M.; UEMURA, T.; NOGUCHI, H.; KONDO, A.; TANAKA, N.; NAMBA, N. Transplantation of highly differentiated immortalized human hepatocytes to treat acute liver failure. Transplantation, v. 69, p. 202-207, 2000.

KOLF, C. M.; CHO, E.; TUAN, R. S. Mesenchymal Stromal cells. Biology of adult mesenchymal stem cells: Regulation of niche, self-renewal and differentiation.

Arthritis Research Therapy, v. 9, p. 204, 2007.

LACONO, E.; MERLO, B.; SAPADARI, A.; MARI, G.; RICCI, F.; TAZZARI, P. Isolation, diferentiation, and immunophenotypic characterization of mesenchymal stem cells derived from equine adipose tissue and bone marrow. Reproduction, Fertility and Development, v. 23, p. 250-251, 2010.

LAMMERT, E.; CLEAVE, R. O.; MELTON, D. Induction of pancreatic differentiation by signals from blood vessels. Science, v. 294, p. 564-567, 2001. 
LANGBEIN, L.; ROGERS, M. A.; WINTER, H.; PRAETZEL, S.; BECHAUS, U.; RACKWITZM H. R.; SCHWEIZER, J. The catalog of human hair keratins I. Expression of the nine type I members in the hair follicle. The Journal of Biological Chemistry, v. 274, n. 19, p. 874-84, 1999.

LATSHAW, W. K. Veterinary development anatomy: a clinical oriented approach. Toronto: Decker, 1987. p. 283.

LEE, Y. M.; KUMAR, B. M.; KIM, S. W.; LEE, S. L.; RHO, G. J. Characterization and differentiation into oocyte-like cell masses of porcine mesenchymal stem cells derived from ovarian theca cells. Reproduction, Fertility and Development, v. 23, n. 1, p.186-187, 2010.

LEISER, R.; KAUFFMANN, P. Placental structure: in a comparative aspect. Experimental Clinical Endocrinology, v. 102, n. 3, p. 122-134, 1994.

LI, L.; XIE, T. Stem cell niche: structure and function. Annual Review of Cell and Devolpmental Biology, v. 21, p. 605-631, 2005.

LI, M.; MA, W.; HOU, Y.; SUN, X. F.; SUN, Q. Y.; WANG, W. H. Improved isolation and culture of embryonic stem cells from Chinese miniature pig. The Journal of Reproduction and Development, v. 50, p. 237-244, 2004.

LIWSKA, J.; GRABINSKI-BARANOWSKI, A. J. Ultrastructure of the secondary yolksac in pig's embryo. Folia Morphology, v. 53, p. 269-283, 1994.

LONG, M. W. Osteogenic and boné-marow-derived cells. Blood Cells. Molecules and Disease, v. 27, n. 3, p. 677-690, 2001.

MACHADO, G. F.; FIGUEIREDO, F. Revisão: Filamentos Intermediários. Medicina, Ribeirão Preto, v. 29, p. 104-113, 1996.

MANÇANARES, C. A. F. Analise morfológica da área de transição do intestino primitivo para o saco vitelino em embriões e fetos bovinos (24 a 50 dias de gestação). 2007. 115 f. Tese (Doutorado em Medicina Veterinária) - Faculdade de Medicina Veterinária e Zootecnia, Universidade de São Paulo, São Paulo, 2007.

MARRABLE, A. W. The embryonic pig: a chronological account. London, England: Sir Isaac Pitman and Sons, 1971. 130 p. 
MARSHALL, M. A. Marshall's physiology of reproduction. London: A. S. Parkes, Logman's Green, 1952. 842 p.

MATSUMOTO, K.; YOSHITOMI, H.; ROSSANT, J.; ZARET, K. S. Liver organogenesis promoted by endothelial cells prior to vascular function. Science, $v$. 294, p. 559-563, 2001.

MCGRATH, K. E.; PALIS, J. Hematopoiesis in the yolk sac: more than meets the eye. Experimental Hematology, v. 33, n. 9, p. 1021-1028, 2005.

MEIRELLES, L. S.; CHAGASTELLES, P. C.; NARDI, N. B. Mesenchymal stem cells reside in virtually all post-natal organs and tissues. Journal of Cell Science, v. 119, p. 2204-2213, 2006.

MELTON, D. A.; COWAN, C. "Stemness": definitions, criteria, and standards. In: LANZA, R. Handbook of stem cells. San Diego: Elsevier Inc, 2004. 804 p.

MEROK, J. R.; SHERLEY, J. L. Breaching the kinetic barrier to in vitro somatic stem cell propagation. Journal of biomedicine \& biotechnology, v. 1, p. 25-27, 2001.

MOORE, K.; PIEDRAHITA, J. A. The effects of human leukemia inhibitory factor (hLIF) and culture medium on in vitro differentiation of cultured porcine inner cell mass (plCM). In vitro cellular \& developmental biology-Animal, v. 33, p. 62-71, 1997.

MOSSMAN, H. W. Vertebrate fetal membranes. New Brunswick: Rutgers University Press, 1987. 383 p.

NIIMI, G.; USUDA, N.; SHINZATO, M. A light and electron microscopic study of the mouse visceral yolk-sac endodermal cells in the middle and late embryonic periods, showing the possibility of definitive erythropoiesis. Annals of Anatomy, v. 184, p. 425-429, 2002.

NETTO, G. C.; BLEIL, C. B.; HIBIG, A.; COUTINHO, L. M. Immunohistochemical evaluation of the microvascular density through the expression of TGF-b (CD 105/endoglin) and CD 34 receptors and expression of the vascular endothelial growth factor (VEGF) in oligodendrogliomas. Neuropathology, v. 28, n. 1, p. 17-23, 2008.

NODEN, D. M.; DE LAHUNTA, A. Embriologia de los animales domésticos. Espanha: Acribia, 1990. 399 p. 
NONES J. Perspectivas para a aplicação de células-tronco embrionárias na clínica veterinária. PUBVET, v. 2, n. 45, ed. 56, Art. 12, 2008. Disponível em: http://www.pubvet.com.br/artigos_det.asp?artigo=12. Acesso em: 24 out. 2011.

NOTARIANNI, E.; LAURIE, S.; MOOR R. M.; EVANS, M. J. maintenance and differentiation in culture of pluripotential embryonic cell lines from pig blastocysts. Journal of reproduction and fertility. Supplement, v. 41, p. 51- 56, 1990.

PALIS, J.; YODER, M. C. Yolk-sac hematopoiesis: the first blood cells of mouse and man. Experimental Hematology, v. 29, p. 927-936, 2001.

PARK, H. W.; SHIN, J. S.; KIM, C. W. Proteome of mesenchymal stem cells.

Proteomics, v. 7, p. 2881-2894, 2007.

PIEDRAHITA, J. A.; ANDERSON, G. B.; BONDURANT, R. H. On the isolation of embryonic stem cells: Comparative behavior of murine, porcine and ovine embryos. Theriogenology, v. 34, p. 879-901, 1990.

PITTENGER, M. F.; MACKAY, A. M.; BECK, S. C.; JAISWAL, R. K.; DOUGLAS, R.; MOSCA, J. D.; MOORMAN, M. A.; SIMONETTI, D. W.; CRAIG, S.; MARSHAK, D. R. Multilineage potential of adult human mesenchymal stem cells. Science, v. $284, n$. 5411, p. 143-147, 1999.

POON, R. T.; FAN, S. T.; WONG, J. Clinical implications of circulating angiogenic factors in cancer patients. Journal Clinical of Oncology, v. 19, n. 4, p. 1207-1225, 2001.

PROCKOP, D. J. Marrow stromal cells as stem cells for nonhematopoetic tissues. Science, v. 276, p. 71-74, 1997.

RALSTON, A.; ROSSANT, J. The genetics of induced pluripotency. Reproduction, v. 139 , p. $35-44,2010$

REEVES, J. T.; DAOUD, F. S.; GENTRY, M.; EASTIN, C. Changes in urinary flow in bovine fetuses during late gestation: composition of amniotic and fetal body fluids. American Journal of Veterinary Research, v. 33, p. 2159-2167, 1972.

RINGE, J.; KAPS, C.; SCHMITT, B.; BUSCHER, K.; BARTEL, J.; SMOLIAN, H.; SCHULTZ, O.; BURMESTER, G. R.; HAUPL, T.; SITTINGER, M. Porcine mesenchymal stem cells: Induction of distinct mesenchymal cell lineages. Cell Tissue Research, v. 307, p. 321-327, 2002. 
RODDA, D. J.; CHEW, J. L.; LIM, L. H.; LOH, Y. H.; WANG, B.; NG, H. H., ROBSON, P. Transcriptional regulation of nanog by OCT4 and SOX2. The Journal of Biologic Chemestry, v. 280, p. 24731-24737, 2005.

ROJAS, M.; MARTÍNEZ-GARCÍA, F.; COBO, P.; PALACIOS, J.; NISTAL, M. REGADERA J. Keratinas: Biología celular y significado funcional normal y patológico. Revista Chilena de Anatomia, v. 16, p. 15-31, 1998.

SABATINI, F.; PETECCHIA, L.; TAVIAN, M.; JODON DE VILLEROCHE, V.; ROSSI, G. A.; BROUTY-BOYE, D. Human bronchial fibroblasts exhibit a mesenchymal stem cell phenotype and multilineage differentiating potentialities. Laboratory

Ivestigation, a journal of the technical methods and patology, v. 85, n. 8, p. 962-971, 2005.

SANTOS, A. C.; BERTASSOLI, B. M.; OLIVEIRA, F. D.; ASSIS NETO, A. C.; MIGLINO, M. A. Circulação Vitelina: analise comparativa. Revista Cientifica Eletrônica de Medicina Veterinária, v. 18, p. 1-21, 2012.

SCHAUWER DE, C.; MEYER, E.; VAN DE WALLE, G. R.; SOOM, A. V. Markers of stemness in equine mesenchymal stem cells: a plea for uniformity. Theriogenology, v. 75 , p. 1431-1443, 2011.

SCHWARZE, E. Compêndio de anatomia veterinária: embriologia. Zaragoza: Acribia, 1970.350 p.

SCHLAFER, D. H.; FISHER, P. J.; DAVIES, C. J. The bovine placenta before and after birth: placental development and function in health and disease, Animal Reproduction Science, v. 61, n. 60, p.145-160, 2000.

SHI, W. K.; HOPKINS, B.; THOMPSON, S. Synthesis of apolipoproteins, alphafoetoprotein, albumin, and transferring by the human foetal yolk-sac and other foetal organs. Journal of embryology and experimental morphology, v. 85, p. 191-206, 1985.

SILVA-JUNIOR, H.; BOROJEVIC, R. Terapias Celulares e Células tronco. In: MORAES, A.M.; AUGUSTO, E.F.P.; CASTILHO, L.R. Tecnologia do cultivo de células animais: de biofármacos a terapia celular. São Paulo: Roca, 2007. p. 465479.

SORIA, B.; ROCHE, E.; BERNA, G.; LEON-QUINTO, T.; REIG, J. A.; MARTIN, F. Insulin-secreting cells derived from embryonic stem cell mammalize glycemia in streptozotocin-induced diabetic mice. Diabetes, v. 49, p. 1410-1412, 1999. 
SOUZA, C. F.; NAPOLI, P.; HAN, S. W.; LIMA, V. C.; CARVALHO, A. C. C. Celulastronco mesênquimais: Células ideais para a regeneração cardíaca?. Revista Brasileira de cardiologia Invasiva, v. 18, n. 3, p. 344-353, 2010.

STEVEN, D. H. Placentation in mare. Journal of Reproduction and Fertility Supplement. v. 31, p. 41-55, 1982.

STEINER, P. M.; ROOP, D. R. Molecular and cellular biology of intermediate filements. Annual Review of Biochemistry, v. 57, p. 593-625,1988.

STEWART, K.; MONK, P.; WALSH, S.; JEFFERISS, C. M.; LETCHFORD, J.; BERESFORD, J. N. STRO-1, HOP-26 (CD63), CD49a and SB-10 (CD166) as markers of primitive human marrow stromal cells and their more differentiated progeny: a comparative investigation in vitro. Cell Tissue Research, v. 313, p. 281290, 2003.

STRELCHENKO, N. Bovine pluripotent stem cells. Theriogenology, v .45, p.13140, 1996.

STREULI, C. Extracellular matrix remodeling and cellular differentiation. Current Opinion in Cell Biology, v. 11, p. 634-640, 1999.

STROJEK, R. M.; REED, M. A.; HOOVER, J. L.; WAGNER, T. E. A method for cultivating morphologically undifferentiated embryonic stem cells from porcine blastocysts. Theriogenology, v. 33, p. 901-913, 1990.

TAKASHIMA, Y.; ERA, T.; NAKAO, K. Neuroepithelial cells supply an initial transient wave of MSC differentiation. Cell, v.129, p.1377-1388, 2007.

TALBOT, N. C.; BLOMBERG, L. A.; MAHMOOD, A.; CAPERNA T.J.; GARRET, W. M. Isolation and characterization of porcine visceral endoderm cell lines derived from in vivo 11-day blastocysts. In Vitro Cell Development Biology, v. 43, p. 72-86, 2007.

TALBOT, N. C.; REXROAD JR, C. E.; PURSEL, V. G.; POWELL, A. M.; NEL, N. D. culturing the epiblast cells of the pig blastocyst. In vitro cellular \& developmental biology-Animal, v. 29, p. 543-554, 1993.

TAGAMI, M.; ICHINOSE, S.; YAMAGATA, K.; FUJINO, H.; SHOJI, S.; HIRAOKA, M.; KAWANO, S. Genetic and ultrastructural demonstrations of strong reversibility in human mesenchymal stem cell. Cell tissue Research, v. 312, p. 31-40, 2003. 
THEISE, N. D.; NIMMAKAYALU, M.; GARDNER, R.; ILLEI, P. B.; MORGAN, G.; TEPERMAN, L.; HENEGARIU, O.; KRAUSE, D. S. Liver from bone marrow in humans. Hepatology, v. 32, p.11-16, 2000.

THONSON, J. A.; ITSKOVITZ-ELDOR, J.; SHAPIRO, S. S.; WAKNITZ, M. A.; SWIERGIRL, J. J.; MARSHALL, V. S.; JONES, J. M. Embryonic stem cells lines derived from human blastocysts. Science, v. 282, n. 5391, p.1145-1147, 1998.

THOMSON, J. A., KALISHMAN, J., GOLOS, T. G., DURNING, M., HARRIS, C. P., BECKER, R. A. e HEARN, J. P. Isolation of a primate embryonic stem cell line. Proceedings of the National Academy of Science of the USA, v. 92, n. 17, p.7844-7848, 1995.

TIEDEMANN, K.; MINUTH, W. W. The pig yolk-sac I. Fine structure of the posthaematopoietic organ. Histochemistry and Cell Biology, v. 68, p. 133-146, 1980.

TOLOSA, E. M. C.; RODRIGUES, C. J.; BEHMER, O. A.; FREITAS NETO, A. G. Manual de técnicas histológicas normal e patológica. 2. ed. Barueri: Manoele, 2003. $331 \mathrm{p}$.

TONIOLLO, G. H.; VICENTE, W. R. R. Manual de obstetrícia veterinária. São Paulo: Varela, 1993. p. 124.

TOMASI JR, H. P.; SANTOS, A. C.; MIGLINO, M. A.; ASSIS NETO, A. C. The Origin of Hematopoiesis and Vasculogenesis in the Yolk Sac and the Onset of Intraembriyonic Blood Flow ans Cardiac Function in Mammalians. Revista Cientifica de Medicina Veterinária, v. 10, p. 1-15, 2012.

VALENTINI, L.; URANIO, M. F.; CONSIGLIO, A. L.; GUARICCI, A. C.; CAIRA, M.; VENTURA, M.; L'ABBATE, M.; CREMONESI, F.; DELL'AQUILA, M. E. Isolation, proliferation, and characterization of mesenchymal stem cells from amniotic fluid, aminion, and umbilical cord matrix in the dog. Reproduction, fertility and Development, v. 23, n. 1, p.252-253, 2010.

VASCONCELOS, M. G.; XAVIER, R. L. F.; GORDON-NUNEZ, M. A.; SOUZA, L. B.; FREITAS, R. A.; PINTO, L. P. Endogllina: biomarcador angiogênico para vasos neofromados. Odontologia Clinica e Cientifica, n. 2, p. 541-545, 2011. 
WANG, D.; PARK, J. S.; CHU, J. S.; KRAKOWSKI, A.; LUO, K.; CHEN, D. J.; LI, S. Proteomic profiling of bone marrow mesenchymal stem cells upon transforming growth factor beta1 stimulation. The Journal of Biological Chemistry, v. 15, n. 42, p. 43725-42734, 2004.

WEST, J. A.; PARK, I. H.; DALEY, G. Q.; GEIJSEN, N. In vitro generation of germ cells from murine embryonic stem cells. Natures Protocols, v. 1, n. 4, p. 2026-2036, 2006.

WHEELER, M. B. Development and validation of swine embryonic stem cells: a review. Reproduction, fertility and Development, v. 6, n. 5, p. 563-568, 1994.

WIANNY, F.; PERREAU, C.; HOCHEREAU DE REVIERS, M. T. Proliferation and differentiation of porcine inner cell mass and epiblast cells in vitro. Biology of Reproduction, v. 57, p. 756-764, 1997.

WOBUS, A. M.; BOHELER, K. R. Embryonic stem cells: prospects for developmental biology and cell terapy. Physiological Reviews, v. 85, p. 635-378, 2005.

WOLF, E.; ARNOLD, G.; BAVERSACHS, S.; BEIER, H.; BLUM, H.; EINSPANIER, R.; FROHLICH, T.; HERRLER, A.; HIENDLEDER, S.; KOLLE, S.; PRELLE, K.

REICHENBACH, H-D.; STOJKOVIC, M.; WENIGERKIND, H.; SINWATSZ, F. Embrymaternal communication in Bovine-stagies for deciphering a compley cross-talk.

Reproduction in Domestic Animal, v. 38, p. 276-289, 2003.

WOLPERT, L.; BEDDINGTON, R.; BROCKES, J.; JESSELL, P. L.; MEYEROWITZ, E. Biologia do desenvolvimento. Porto Alegre: Artes Médicas Sul, 2000. 484 p.

WOODING, F. B. P.; FLINT, A. P. F. Placentation In: LAMMING, G. E. Marshall's physiology of reproductive. 4. ed. London: Chapman e Hall, 1994. Pt. 1, p. 743750.

YOUNG, M. F.; KLEIN, N. W. Synthesis of serum proteins by cultures of chick embryo yolk sac endodermal cells. Developmental Biology, v. 100, p. 50-58, 1983.

ZACHAREK, A.; CHEN, J.; CUI, X.; LI, A.; LI, Y.; ROBERTS, C.; FENG, Y.; GAO, Q.; CHOPP, M. Angiopoietin1/Tie2 and VEGF/Flk1 induced by MSC treatment amplifies angiogenesis and vascular stabilization after stroke. Journal of Cerebral Blood Flow and Metabolism, v. 27, p. 1684-1691, 2007.

ZAGO, M. A.; COVAS, D. T. Células Tronco hematopoiéticas. São Paulo: Ahteneu, 
2006. 264 p.

ZHANG, Q.; MADONNA, R.; SHEN, W.; PREIN, E.; ANGELI, F. S.; MURAD, F.; YEH, E.; BUJA, L. M.; DED CATERINA, R.; WILLERSON, J. T.; GENG, Y. Stem cells and cardiovascular tissue repair: mechanism, methods, and clinical application. Journal of Cardiothoracic-Renal Research, v. 1, p. 3-14, 2006. 